This draft: December 31, 2010

\title{
The banking bailout of the subprime crisis: big commitments and small effects?
}

\author{
by
}

\section{Michele Fratianni* and Francesco Marchionne**}

\begin{abstract}
$\underline{\text { Abstract }}$
This paper examines government policies aimed at rescuing banks from the effects of the financial crisis of 2008-2009. Governments responded to the crisis by guaranteeing bank assets and liabilities and by injecting fresh capital into troubled institutions. We employ event study methodology to estimate the benefits of government interventions on banks. Announcements directed at the banking system as a whole were associated with positive cumulative abnormal returns whereas announcements directed at specific banks with negative ones. The effects of foreign general announcements spilled over across different areas and were perceived by home-country banks as subsidies boosting the competitive advantage of foreign banks. Specific announcements produced effects that were consistent with other banks being crowded out for government resources. Multiple specific announcements exacerbated the extent of banks' moral hazard. Results were sensitive to the information environment. Findings are consistent with the hypothesis that individual institutions were reluctant to seek public assistance.
\end{abstract}

JEL Classification: G01, G21, N20

Keywords: announcement, bank, event study, financial crisis, rescue plan.

* Corresponding author, Indiana University, Kelley School of Business, Bloomington, Indiana (USA), Università Politecnica delle Marche and MoFiR, Ancona (Italy), email: fratiann@indiana.edu. ** Università Politecnica delle Marche and MoFiR, Ancona (Italy), email: f.marchionne@univpm.it. 


\section{INTRODUCTION}

The financial earthquake of the subprime crisis, starting in 2007 and further developing in the subsequent two years, generated a tsunami of public interventions into banking systems. In this paper, we examine government policies aimed at rescuing banks from the effects of this crisis. To delimit the scope of the analysis, we concentrate on the fiscal side of interventions and ignore, by design, the monetary policy reaction to the crisis (in essence, we ignore inflation as a possible exit strategy).

The subprime crisis fits many of the characteristics of the credit-boom-and-bust-cycle hypothesis, discussed, among others, by Mitchell (1913), Fisher (1933), Minsky (1977) and Kindleberger (1978); for a review, see Fratianni (2008). Other characteristics, instead, are unique to this crisis, such as the transfer of assets from the balance sheets of banks to the markets, the creation of complex and opaque assets, the failure of ratings agencies to properly assess the risk of such assets, and the application of fair value accounting. The "originate-to-distribute" bank model lowered the incentive of the originator to screen debtors whose loans were to be placed off balance sheet. While reputational considerations would suggest that the originator might not want to compromise its standards, the fact that regulators and accounting standards required little disclosure about unconsolidated off-balance sheet entities made these entities opaque to investors and lowered the cost of reputational loss to the sponsoring institution. To complicate matters, the ratings agencies were not up to the task of properly evaluating the new complex products (Calomiris 2007). In fact, there is evidence that credit standards deteriorated in the United States during the 2001-2007 credit boom, especially in the subprime mortgage market (Demyanyk and van Hembert 2009; Dell'Ariccia et al. 2008). Another problem with the "originate-to-distribute" model stems from the contingency that the off-balance sheet entities could be reabsorbed by the sponsoring institution to either cover large trading losses or prevent a downgrade of the sponsored institution's credit risk (IMF 2008a, Box 2.6). At that point, there would be a reversal of the intended benefits of the "originate-to-distribute" model: 
risk would return home and regulatory capital would rise. The investor, having finally gained transparency in the transaction, would judge correctly that the sponsoring bank was overleveraged and would demand a higher return on capital; this, in turn, would translate into a spot drop of the share price of the consolidated bank.

Governments have intervened massively and repeatedly to support banks during the crisis. We examine the effectiveness of these interventions by measuring the markets' reaction to intervention announcements. To do so, we create an original dataset of public interventions that distinguishes announcements directed at the banking system as a whole (general announcements) from those directed at specific banks (specific announcements). With this dataset, we apply event-study methodology to estimate the value of government interventions to support banks and their shareholders. The maintained hypothesis is that the announcement of a rescue plan is credible if it affects rates of return of the targeted banks. We test for these effects by computing cumulative abnormal returns (CAR) of the participating banks around a window that includes announcement dates. We perform four separate tests on our sample of large banks. One test estimates, with panel data, the overall impact on banks' equity value of the two types of government rescue announcements; a second estimates cross-area spillover effects of general announcements; a third estimates cross-bank spillover effects of specific announcements using US banks; and a fourth considers the impact of multiple specific announcements.

Our findings show that general and specific announcements are priced by the markets as CAR over the selected window periods. General announcements tend to be associated with positive CAR and specific announcements with negative ones. Foreign general announcements exert cross-area spillovers, but are perceived by home-country banks as boosting the competitive advantage of foreign banks. Specific announcements exert spillovers on other banks. Our results are also sensitive to the information environment. Specific announcements tend to exert a positive impact on rates of return 
before the crisis erupts, when announcements are few and markets have relative confidence in the "normal" information flow. The opposite takes place when the crisis explodes, announcements are the order of the day and markets mistrust the information flow. These results appear consistent with the observed reluctance of individual institutions to seek public assistance. Bank size is priced positively by the markets, but there is no clear evidence of too-big-to-fail policy. Specific announcements exacerbate moral hazard of subsided banks and make the banking system more fragile to negative shocks and less sensitive to further injections of public funds.

The paper is organized as follows. Section 2 describes the market reaction to the crisis and shows that Lehman Brothers' failure was a critical event. Section 3 reviews event-study methodology with a focus on the event-parameter application within a regression framework. Section 4 describes our testable models. Section 5 reviews the long list of government announcements to rescue banks and discusses our dataset. We show that governments have employed a mixture of capital injections and bank asset and debt guarantees, and that opaque but politically attractive guarantees have been dominant. Section 6 employs event-study methodology to estimate the impact of government interventions on banks and their shareholders. Conclusions are drawn in the last section.

\section{MARKETS' REACTION TO LIQUIDITY RUSH AND RISK REPRICING}

The first effect of the crisis on the market was a rush for liquidity due to risk repricing of assets. The liquidity crisis exploded in the interbank market in August of 2007. Figure 1 plots TED spreads -the difference between the three-month LIBOR and the three-month Treasury bill- during the entire subprime crisis for three areas of the world: the United States, Europe and the Pacific region. Under 
ordinary times, this spread is contained within 20 to 30 basis points. ${ }^{1}$ From September 15 (the day when Lehman declared bankruptcy) to October 14, 2008, the US TED spread averaged over 300 basis points; on October 10, 2008, the Friday that ended a historic week of panic selling in the equity markets, it reached an all-time peak of 464 basis points. A similar story holds for the TED-equivalent spreads of the large European countries and Hong Kong. Japan, on the other hand, stands out as a country of moderate risk. On March 9, 2009, the bottom of stock market value, the TED spread had regained the pre-crisis level in the United States, United Kingdom and Hong Kong, but not in Europe where the risk remained high for additional three months.

\section{[Insert Figure 1 here]}

The markets were gripped by fears of credit and liquidity risks, two risks distinguishable in theory, but not in practice (IMF 2008b, pp. 78-81). The massive injections of monetary base by central banks were ineffective in containing the spreads in the interbank market because market participants were worried about large credit risks and adverse selection, and could not separate liquidity from credit risk concerns. Spreads relative to yields on government bonds shot up across all maturities (IMF 2008b, pp. 172-3). ${ }^{2}$ The switch in the public's degree of risk aversion was justified by the mounting difficulty of gathering reliable information on opaque clients in times of distress. Confronted with more uncertainty in assessing the true credit status of relatively opaque borrowers, creditors had no better method than applying higher interest rates to entire classes of borrowers. The fog shrouding banks' balance sheets and the financial markets was reinforced by opaque accounting practices (Fratianni and Marchionne 2009). ${ }^{3}$

\footnotetext{
${ }^{1}$ At the peak of the Mexican crisis of 1994-95 and the South-East Asian financial crisis of 1997, the TED spread rose to approximately 60 basis points. In the Gulf War and the crisis of Long Term Capital Management, it peaked at approximately 120 basis points.

${ }^{2}$ See Mishkin (1991) for historical evidence from the $19^{\text {th }}$ and $20^{\text {th }}$ century US panics.

${ }^{3}$ To illustrate, according to reported accounting data, the US banking system did not appear severely undercapitalized: at the end of 2008, the ratio of Tier 1 or core capital to risk-weighted assets was 17.4 percent for small banks, 12.3 percent for intermediate banks, and 9.4 percent for large banks. These ratios are way above the benchmark of 4 percent. Yet, it was
} 
The shrinking of balance sheets and the re-pricing of risk across a variety of assets triggered a process of deleveraging, as predicted by the credit-boom-and-bust hypothesis. From the second half of 2007 through September 2008, deleveraging of global banks was met with $\$ 430$ billion of fresh capital (IMF 2008b, p. 22). Then, with recapitalization becoming increasingly difficult, deleverage was achieved by selling assets in illiquid markets. Thus, without significant profits to retire debt or fresh capital to finance it, the deleveraging process necessarily implied distress sales and falling asset values (Adrian and Shin 2008, Figure 2.5). Fair value accounting aggravated the problem through its procyclical bias. Lower accounting asset prices impacted negatively on regulatory capital and may have pushed bankers to engage in liquidation sales that further depressed asset prices.

Stock market data show the extent of the financial maelstrom. We collect equity prices for a sample of banks from three areas of the world: the United States, Western Europe, and the Pacific region. The actual list, shown in the Table A1 of the Appendix, includes 45 US banks, 51 banks from 15 different Western European countries, and 26 banks from three different Pacific region countries; more on our data below. ${ }^{4}$ The listed banks tend to be large and thus capable of engaging in complex structured finance. Table 1 provides average rates of return, both in local currency and in US dollars, at the country level for three periods: the first phase of the crisis from the starting pre-crisis date of July 31, 2007 to September 15, 2008, an expanded phase of the crisis from the same starting date to March 9, 2009, and the complete sample period from the same starting date to our last observation of December 31, 2009. September 15, 2008 is a significant date because it is the day when Lehman Brothers filed for Chapter 11 bankruptcy protection, an event widely believed to be a watershed in the crisis; March 9, 2009 was selected because is the date when the market finally bottomed out.

widely acknowledged that banks were severely undercapitalized. Undercapitalization has been the biggest stumbling block to the resolution of the financial crisis.

${ }^{4}$ Only the largest listed banks are included. For Ireland, Norway, and Switzerland, we have one bank each. 
[Insert Table 1, here]

Over the extended period from July 31, 2007 to March 9, 2009, the crisis destroyed \$3.34 trillion of market values in our bank sample. European banks were hit the hardest with a 79.94 percent decline, the Pacific banks were hit the mildest with a 52.13 percent decline, and US banks fared in the middle with a 76.42 percent decline. The decline, furthermore, was at least twice as large after September 15, 2009 than in the first phase of the crisis. Table 1 shows rates of return both in local currency and in US dollar. Dollar returns are the sum of local-currency returns, the rate of dollar depreciation (or appreciation if negative) and the interaction between these two terms. The US dollar depreciated relative to most currencies in the pre-Lehman period, appreciated in the first part of the post-Lehman period and then depreciated again after May of 2009. Consider bank stocks in the euro area. In the pre-Lehman period, rates of return averaged -37 percent, over a range spanning from -32 percent for Greece to -61 percent for Ireland. Banks from France, Germany, Ireland, and Portugal fared worse than banks from Greece, Italy, Spain, and Netherlands. From July 31, 2007 to March 9, 2009 , the euro-area average rate of return was an astounding - 74 percent, ranging from -64 percent for Spain to -98 percent for Ireland. Austrian, Belgian, Dutch, German and Irish banks did much worse than French and Southern European banks. For most countries, but not for the United Kingdom, Norway, Sweden, and Australia, the differences between local-currency returns and US dollar returns were of a small order of magnitude.

At first, governments reacted to the crisis with disjointed and ad-hoc interventions, which were accompanied by sharp declines in equity prices. For example, the US government supported some institutions (Bear Stearns being acquired by JPMorgan Chase), but not others (Lehman Brothers). The failure of Lehman on September 15, 2008 was a watershed and prompted policymakers in the next two months to implement programs addressing systemic problems, such as the $\$ 700$ billion Troubled Asset Relief Program (TARP) in the United States and the $£ 500$ billion banking recapitalization program in 
the United Kingdom. The initial objective of purchasing sub-standard illiquid assets ran into difficulties because, without a market, governments were likely to either overvalue "toxic" assets, thus penalizing taxpayers, or undervaluing them, thus penalizing potential sellers. Governments then adjusted their policy by either recapitalizing financially distressed banks (e.g., in the United States) or nationalizing them (e.g., in the United Kingdom). In December 2008 and January 2009, governments tried to douse the fire of the crisis by targeting specific large banks (e.g., Commerzbank and Citigroup); they were unsuccessful. In February and March 2009, additional general measures were taken, this time with a focus on relieving banks of bad assets. At the same time, many indebted US banks began repaying the US government, while in Europe the number of banks that had signaled their intention for government assistance declined (e.g., Intesa Sanpaolo and Unicredit in Italy).

\section{METHODOLOGY}

The rescue of several large financial institutions in the United States and in Europe was sparked by the migration of liquidity risk from banks to other financial institutions and followed the rapidly expanding role of government as a market maker of last resort to support not only big banking, but also big finance. We employ event-study methodology to estimate markets' reaction to the announcements of government interventions.

Event-study methodology goes back to the 1930s (Dolley 1933), but became ubiquitous in capital markets research after important contributions by Ball and Brown (1968) and Fama et al. (1969). ${ }^{5}$ The spreading popularity of this technique, however, was accompanied by modifications of the original setup that implied violations of the underlying statistical assumptions (MacKinlay 1997). Corrections and practical adjustments to these practices surfaced in the second half of 1970s; for a

\footnotetext{
${ }^{5}$ Kothari and Warner (2006) report that, over the period 1974-2000, five top finance journals published 565 articles using event-study methodology.
} 
review, see Serra (2002) and Corrado (2009). There is now agreement that the general setup of this methodology consists of three stages: the identification of an event of interest and its timing; the specification of a valuation model; and an analysis and computation of CAR (cumulative abnormal returns) around the event date (De Jong 2007, p. 2). The procedure can be implemented in two alternative ways (Binder 1998). The first is a two-step approach, in which a valuation model is first estimated over a control (pre-event) estimation period and then CAR is computed as cumulative residuals of the valuation model over a short event window; for an example, see O'Hara and Shaw (1990). The second is an event-parameter approach, in which the valuation model is estimated over the combined estimation and event periods, and includes dummy variables defined (to be equal to one) over a relevant event window; for an example, see Meulbroek (1992).

The two approaches are unbiased and equivalent under the assumption of serially independent and normally distributed returns and non-overlapping event windows (Corrado 2009). Conversely, problems arise in the presence of overlapping windows, multiple events, aggregation of abnormal returns across firms, cross-sectional dependence, serial correlation, event-induced volatility and eventinduced returns (De Jong 2007). A number of these statistical problems can be overcome with the event-parameter regression framework (Binder 1998). In our case, general announcements are clearly overlapping because they influence all banks in a country; furthermore, if different countries were to coordinate their policies overlapping would be exacerbated. Also, public interventions become multiple events when the same bank receives subsidies repeatedly during the crisis. In the presence of overlapping multiple events, Binder (1998) suggests the use of event-parameter methodology because it simplifies the estimation and is more flexible in hypothesis testing. This methodology provides also a natural solution to aggregation problems across banks. Other considerations as well support the choice of the event-parameter framework: with relatively frequent events, as it is true in our case, information on multiple events is lost or distorted by the two-step approach because the estimation window is either 
too short or affected by previous announcements. The event-parameter methodology is relatively more efficient because abnormal returns are estimated in one step. ${ }^{6}$

\section{TESTABLE MODELS}

We propose four separate tests using the event-parameter methodology. The first aims at uncovering the overall impact on banks' equity value of general and specific announcements; the second at identifying the cross-area spillover effects of general announcements; the third at unveiling the crossbank spillover effects of specific announcements; and the last test focuses on multiple specific announcements.

In the first test, daily rates of returns on bank stock $i$ of country $j$ at time $t, R_{i j t}$, are regressed on an intercept, capturing the risk-free rate of return and on the market rate of return, $R_{j t}^{M}$, and two dummy event variables. The first dummy variable, $G_{j t}$, is equal to one during the event time window, $T$, around a general announcement; otherwise it is zero. The second dummy variable, $S_{i t}$, is equal to one in the time window $T$ around a specific announcement. We also break down $G$ and $S$ by different intervention types, such as capital injections and asset and debt guarantees. The test is formalized as follows:

$$
R_{i j t}=\alpha+\beta \cdot R_{j t}^{M}+\gamma \cdot G_{j t}+\delta \cdot S_{i t}+u_{i j t}
$$

where $u$ denotes a well-behaved error term and $G$ and $S$ become dummy vectors when we disaggregate by intervention type. ${ }^{7}$ Markets' reactions to announcements are captured by $\gamma$ and $\delta$ : returns within the time window $T$ are predicted to be higher than returns in other periods; that is, the government-

\footnotetext{
6 Furthermore we employ robust standard errors and cluster correction to reduce problems of serial correlation and heteroskedasticity.

${ }^{7}$ In this case, the extended formulation is:

$$
R_{i j t}=\alpha+\beta \cdot R_{j t}^{M}+\gamma^{C A P} \cdot G_{j t}^{C A P}+\delta^{C A P} \cdot S_{i t}^{C A P}+\gamma^{G U A} \cdot G_{j t}^{G U A}+\delta^{G U A} \cdot S_{i t}^{G U A}+u_{i j t}
$$

where $C A P$ and GUA indicate, respectively, capital injection and asset and debt guarantees.
} 
intervention event generates CAR. Since the error of the regression must be zero on average, the null hypothesis is that CAR, within $T$, must also be zero. A rejection of the null hypothesis corroborates the presence of abnormal returns. In (1), CAR is the sum of the estimates of parameters $\gamma$ and $\delta$ multiplied by $T$ (Meulbroek 1992).

The second test uses bank data from each of the three areas, as in (2):

$$
R_{i t, j}=\alpha_{j}+\beta_{j} \cdot R_{t, j}^{M}+\gamma_{j} \cdot G_{t, j}+\delta_{j} \cdot S_{i t, j}+\sum_{k=1}^{3} \theta_{k, j} \cdot X A G_{t k, j}+u_{i t, j}, \quad j=1,2,3
$$

There are two differences with respect to equation (1). The first is that coefficients are now denoted with a subscript " $j$ " to indicate that they are area specific. The second is that (2) adds three cross-area general announcement dummies, $X A G_{k, j}$, where $k$ is the area broadcasting $G$ and $j$ another area receiving the potential impact of $G$ : for example, $X A G_{3,1}$ captures the $G$ effect of area 3 (say, Pacific) on area 1 (say, US). Cross effects can also occur among countries located in the same area (for example Australia impacting Japan). Such within-area cross effects are denoted by $X A G_{j, j}{ }^{8}$ In (2), CAR is equal to the estimate of $\theta_{k, j}$ times $T$.

The third test focuses on cross-bank spillover effects of specific announcements, $S$. The motivation for this experiment is that during a crisis markets are shrouded in a fog of ignorance about the true extent of banks' difficulties. The news that one large bank will be receiving government support sends two separate signals. One signal is that if government saves a large bank, it is also likely to save another large bank (too-big-to-fail effect); the other signal is that government will have fewer resources to deploy for other large banks (resource crowding-out effect). The Lehman's failure shook

\footnotetext{
${ }^{8}$ Note that $X A G_{j, j}$ is not collinear with $G_{j}$ because we use country data.
} 
the markets exactly because it was a glaring exception to the too-big-to-fail principle. ${ }^{9}$ Given the limitations of our data, we restrict the test to US banks $(k=1)$.

We perform the test in two alternative ways. In the first version, we group US banks in tertiles to estimate effects of cross-group specific announcements, $X G S_{j, i}$.

$$
R_{i t, g}=\alpha_{g}+\beta_{g} \cdot R_{t, g}^{M}+\gamma_{g} \cdot G_{t, g}+\delta_{g} \cdot S_{i t, g}+\sum_{k=2}^{3} \theta_{k, g} \cdot X A G_{t k, g}+\sum_{z=1}^{3} \lambda_{z, g} \cdot X G S_{t z, g}+u_{i t, g}, g=1,2,3(3 \mathrm{a})
$$

where subscript $j$ was dropped because all $i$ banks are located in the same country and subscript $g$ is added for tertiles. $X G S_{t z, g}$ indicates cross-specific announcements of bank group $z$ on group $g$, except for those of bank $i$. Coefficient $\gamma_{g}$ captures the effect of US general announcements, $\delta_{g}$ the effect of specific announcements for the $i^{\text {th }}$ bank, $\theta_{k, g}$ the effect of cross-general announcements from Europe and the Pacific area, and $\lambda_{z, g}$ the effect of specific announcements from bank group $z$ on the $g^{\text {th }}$ group, except those of bank $i$.

In the second version, we test the too-big-too-fail policy among the largest US banks. The formulation of the test is given by equation $(3 b)$ :

$$
R_{t, i}=\alpha_{i}+\beta_{i} \cdot R_{t, i}^{M}+\gamma_{i} \cdot G_{t, i}+\delta_{i} \cdot S_{t, i}+\sum_{k=2}^{3} \theta_{k, i} \cdot X A G_{t k, i}+\sum_{h=1, h \neq i}^{7} \lambda_{h, i} \cdot X B S_{t h, i}+u_{t, i}, \quad i=1, \ldots, 7
$$

where $X B S_{h, i}$ indicates the cross-specific announcement of bank $h$ on bank $i$. Note that the own specific announcement $S$ is equal to the cross-specific announcement $X B S$ when $i=h$. Coefficients are the same of equation (3a), except for $\lambda_{h \neq i}$ that captures the effect of a specific announcement of the $h^{\text {th }}$ bank (say, Citigroup, J.P. Morgan, Wells Fargo, Goldman Sachs, American Express, and Morgan Stanley) on the $i^{\text {th }}$ bank (say, Bank of America).

In the final test, we focus on the effects of multiple specific announcements. One reason why such announcements are repeated may stem from the incomplete nature of the information available to

\footnotetext{
${ }^{9}$ For evidence of the too-big-to-fail principle, see O'Hara and Shaw (1990).
} 
governments. Banks tend to hide their financial difficulties to avoid the cost of higher risk premium on own debt and equity. Furthermore, the granting of the subsidy can induce the targeted bank to either be more prudent or more opportunistic (moral hazard), depending on whether the government makes the subsidy conditional on tough requirements and strict monitoring or not. If requirements are perceived excessive, the targeted bank may decide to forego the subsidy. We test bank behavior with equation (4):

$$
R_{i j t}=\sum_{c=0}^{2}\left(\alpha_{c}+\beta_{c} \cdot R_{j t, c}^{M}+\gamma_{c} \cdot G_{j t, c}+\delta_{c} \cdot S_{i t, c}\right)+u_{i j t}
$$

where $c$ is the number of specific announcements received by the $i^{\text {th }}$ bank. We do not consider $c>2$ because we have too few observations. Using $c=0$ as a benchmark, negative $\alpha_{1}$ and $\alpha_{2}$ and positive $\beta_{1}$ and $\beta_{2}$ are consistent with an opportunistic behavior. Coefficients $\gamma_{1}$ and $\gamma_{2}$ capture the effect of additional general announcements, $\delta_{1}$ and $\delta_{2}$ the effect of additional specific announcements on the $i^{\text {th }}$ bank.

\section{DATA}

Our dataset consists of daily rates of return on 122 large listed banks from 19 countries and national market indices from July 31, 2007 to December 31, 2009. The listed banks are shown in Table A1 of the Appendix; Bloomberg is the source of the data. We also collected announcement dates of government rescue plans over the same period. As mentioned, we classify two types of rescueannouncement events: $G$, whereby the government declares its intention to protect the entire national banking system, and $S$ aimed at saving specific banks; see Tables A2 and A3, respectively, in the Appendix. We used a variety of sources for the compilation of general and specific announcements: BNP Paribas (2009), DLA Piper (online), International Capital Market Association (online), 
Mediobanca (2009), Panetta et al. (2009), and websites of CNN Money and national Ministries of Finance or Treasuries.

For the 19 countries represented in our sample, there are 51 general announcements over 33 different dates, of which 30 are capital injections and 21 are asset and debt guarantees (Appendix, Table A2). There are 139 specific announcements over 88 different dates, of which 103 as capital injections and 36 as asset and debt guarantees (Appendix, Table A3). Specific announcements affect 53 of the 122 banks and two thirds of the countries in our sample. ${ }^{10}$ Pacific-area banks are the least affected by announcements. Finally, 33 banks in our sample have been the target of multiple announcements.

From the date of Lehman's failure to the end of 2009, governments have committed $\$ 8.6$ trillion of funds in general rescue packages, of which 37.6 percent as capital injections and 63.4 percent as asset and debt guarantees; see Appendix, Table A2. The rescue plans of the United States, United Kingdom, Germany and Ireland were larger than those of Italy, Denmark, Greece, and Portugal. Clearly, differences in the committed amounts cannot be explained only by differences in national sizes of financial markets.

Commitments to specific interventions, over the same period, amount to $\$ 2.4$ trillion, of which 39.9 percent as capital injections and 60.1 percent as asset and debt guarantees (Appendix, Table A3). The ranking of subsidy-receiving banks changes according to the type of intervention. Considering all subsidies, the Royal Bank of Scotland and Lloyds TBS top the list, respectively with $\$ 529$ and \$408 billion, followed by Citigroup and Hypo Real Estate with $\$ 330$ billion each, Dexia with $\$ 228$ billion and Bank of America with \$144 billion.

\footnotetext{
${ }^{10}$ These countries are Austria, Belgium, France, Greece, Germany, Ireland, Italy, Luxembourg, Netherlands, Portugal, Sweden, the United Kingdom, and the United States.
} 
In sum, governments have used a mix of general and specific interventions, reflecting the opaqueness of information after Lehman's failure. Asset and debt guaranties are politically attractive because governments do not have to argue the case with legislators. They also entail smaller current costs than the expected present-value contingent cost, suggesting that governments are prone to gamble for a possible resurrection of the banking system. This strategy was a defining characteristic of both the US Savings and Loans crisis of the Eighties and the long Japanese crisis of the Nineties, which was responsible for transforming "a relatively small cost into a staggeringly large one" (Glauber 2000, p. 102).

Table 2 reports some descriptive statistics for the pre-Lehman and post-Lehman failure periods; for brevity, we shall refer to these two periods as PRE and POST, respectively. Bank returns $R_{i}$ tend to be procyclical in both periods. The variability of $R_{i}$ (measured by its standard deviation) is higher than the variability of market returns, $R_{m}$, and rises from $P R E$ to $P O S T$. Both individual $\left(S I Z E_{i}\right)$ and overall $\left(S I Z E_{m}\right)$ market capitalizations of banks decrease around 35 percent from PRE to POST, implying no material change in relative bank size (SIZEREL). The within serial variability of $S I Z E_{i}$ falls from 45 to 36 between the two periods, whereas the overall variability of $S I Z E_{o}$ rises from 444 to 738 , implying an increase in the between cross-sectional variability. The main message is that the financial crisis enlarged size differences among banks.

[Insert Table 2, here]

\section{FINDINGS}

The hypothesis underlying our analysis is that the announcement of a rescue plan is credible if it raises the survivability and rates of return of participating banks. Therefore, we can test the effects of rescue plans by computing CAR of participating banks around an announcement-date window. Estimates of alpha, the risk free rate, and beta, the market risk parameter, from the capital asset price model are estimated on daily returns for the $P R E$ and $P O S T$ periods. A general announcement is more complex 
than a specific announcement because it requires longer time for the market to process it; in addition, it is easier for the markets to obtain relevant information about general than specific announcements. For this reason, we apply different windows to the two types of announcements: a seven-day window for general announcements centered on the announcement date and spanning three working days before and after the announcement, and a five-day window for specific announcements centered on the announcement date and spanning two working days before and after the announcement. We exclude UK banks from the estimation because UK capital injections were in fact nationalizations that tend to be unfavorable to private shareholders and can distort market reactions. ${ }^{11}$ Consequently, the number of banks in our sample is reduced to 116.

\section{$\underline{5.1 \text { Overall impact of general and specific announcements on banks' rates of return }}$}

The first test estimates the overall impact of 49 general and 133 specific announcements on banks' returns using the entire panel of 116 banks. ${ }^{12}$ Results for the two periods are shown in Table 3: PRE has 33,189 observations and POST 38,745, of which 15,060 from the United States, 15,065 from Europe, and 8,620 from the Pacific area. We test equation (1) first by aggregating all announcements $(A L L)$ and then using the two individual categories of capital injections $(C A P)$ and asset and debt guarantees (GUA); see equation (1b). We recall that a general announcement $G$ has a seven-day window and a specific announcement $S$ a five-day window. We experimented with different window lengths: results tend to weaken as the window is enlarged, in particular for $S$. Obviously, the bulk of

\footnotetext{
${ }^{11}$ For example, partial nationalization reduces the volume of traded shares that, in turn, affects stock price. Conversely, public ownership provides an explicit safety net.

${ }^{12}$ We drop announcements from the United Kingdom (two general announcements and six specific announcements).
} 
the announcements occurs in POST. The panel is estimated with bank fixed effects, a specification that is not rejected by the Hausman (1978) test. ${ }^{13}$

In addition to the variables indicated on the right-hand side of equation (1), we have added relative bank size measured as the US dollar capitalization value of bank $i$ relative to capitalization of all banks (SIZEREL). This variable turns out to have positive and statistically significant effects in all the regressions. On average, 0.35 percentage points of returns depend on SIZEREL in PRE and over 0.45 in POST. Relevant differences emerge among banks. Take Hypo Real Estate, Banca Monte dei Paschi di Siena, and Bank of New York Mellon, respectively the first quartile, median, and third quartile in the distribution of market-value capitalization in PRE. SIZEREL impact on returns of Hypo Real Estate is nine times lower than on returns of Banca Monte dei Paschi and 25 times lower than on returns of Bank of New York Mellon.

The first key finding of Table 3 is that all announcements have a statistically significant and economically relevant impact on banks' rates of return. ${ }^{14}$ The PRE period has no general announcements $G$ and relatively few specific announcements $S$, which produce a CAR of 8.8 percentage points. In the POST period, $G$-induced CAR are almost 5 percentage points higher than normal returns while $S$-induced CAR are 1.7 percentage points lower than normal returns. The opposite signs of the $G$ and $S$ coefficients reflect differences in the way markets evaluate the two types of announcements. A general announcement is taken as a signal that government wants to protect the

\footnotetext{
${ }^{13}$ The Hausman (1978) specification test uses the statistic $H=N\left(\beta_{F E}-\beta_{R E}\right)^{\prime} \operatorname{Var}\left(\beta_{F E}-\beta_{R E}\right)^{-1}\left(\beta_{F E}-\beta_{R E}\right)$ to compare fixed effects with random effects, where $N=$ number of observations, $\beta_{F E}$ and $\beta_{R E}$ are respectively the vector of coefficients in the fixed and random effect model, and $\operatorname{Var}($.$) indicates the variance-covariance operator; H$ has a chisquared distribution. In Table 3, except for the last column, the null hypothesis that the estimated coefficients from the fixed effect model is not systematically different from the coefficients of the random effect model is rejected at the significance level of 5\%. In this case, that is under the alternative hypothesis, the random-effect model is inconsistent, where the fixed-effect model is. In the last column, observations decrease and the null hypothesis is rejected at the significance level of $10 \%$.

${ }^{14}$ WALD tests of null announcement effects are rejected in all specifications at 5 percent level, except for first period (column 1) rejected at 10 percent level.
} 
banking systems. The banking industry, as a whole, receives support and shareholders gain "abnormally" high rates of return over the announcement window. A specific announcement, instead, generates a more problematic signal. During "normal" times, when markets face stable information flows and are able to price banks' future net cash flows with relative efficiency, $S$ is evaluated as a boost to shareholders' return. On the other hand, in the fog of a financial crisis, when markets are extremely uncertain about the quality of the assets, a specific announcement is taken as a revelation of partially unknown troubles. $S$-induced CAR, therefore, may turn out to be negative. On this point, it is worth recalling that particularly hectic activities took place in the first half of October 2008, when governments intervened on a big scale to stabilize their banking systems; see Figure 2. Over a threeweek period, policy makers first decided to guarantee or purchase assets $(G U A)$, then to inject fresh capital into banks $(C A P)$, and finally to guarantee bank debts $(G U A)$. The speed with which new strategies were introduced underscores the state of confusion, if not outright panic, enshrouding government decisions. Capital markets were extremely opaque in the immediate wake of Lehman's failure.

Differences in the information environment appear to be corroborated by CAR patterns in the two periods: specific announcements have a positive impact on $R_{i}$ in $P R E$, when announcements were few and markets had relative confidence in the "normal" information flow (column 1); but negative in the turbulent POST when announcements were the order of the day and markets mistrusted the information flow (column 2). These results appear consistent with the observed reluctance of individual institutions to ask for public assistance. The fear of being identified as a "bad apple" was also the reason why some banks were reticent to seek emergency lending from central banks.

In column 3, the base model is expanded with interactive terms between market returns and the two announcement dummies, so as to capture abnormal betas. We find a negative (positive) abnormal market risk for general (specific) announcements, a pattern that corroborates the earlier result 
that general announcements provide a safety net to banking system whereas specific announcements appear to identify "bad apple" banks. We also check, in column 4, for potential too-big-too-fail effect by adding interactive terms between SIZEREL and announcement dummies; we find no evidence of that.

The second key finding of Table 3 is that markets have had difficulties in sorting out the relative efficacy of different types of announcements. Column 5 reports the estimate of the base model and columns 6 through 9 the estimates of the expanded model. Both $G^{C A P}$ and $G^{G U A}$ exert a positive impact on $R_{i}$. On the other hand, the negative impact of $S$ on $R_{i}$ is driven wholly by $S^{C A P}$. Area regressions confirm this pattern. In column 6, abnormal betas are estimated by intervention types: general announcements of asset and debt guarantees lower beta, whereas general announcements of capital injections and the two types of specific announcements raise beta. Columns 7 through 9 underscore differences of abnormal market risk in the three areas. In particular, the US market stands out as somewhat different with respect to other areas.

[Insert Table 3 and Figure 2, here]

A point of interest is to check the stability of the coefficient estimates over the most turbulent part of the crisis. To this end, we run rolling regressions of the base model recursively, starting with an initial estimation window spanning from July 31, 2007 to July 31, 2008 and then expanding it progressively until the end of 2009. Figure 3 plots the rolling estimates of $R_{m}$, SIZEREL, $G^{A L L}$ and $S^{A L L}$. The impact of market risk rises sharply immediately after Lehman's failure, then declines rapidly in the latter part of 2008, and finally rises steadily until June 2009. As to relative bank size, its effect on bank returns doubles after Lehman's failure and stays high until the bottom of the markets, after which it falls to around one half of its pre-Lehman value. These patterns confirm that Lehman's failure was a watershed in the crisis and that ensuing turbulence lasted approximately six months. Both general and specific announcements had positive effects on bank returns soon after Lehman's demise, but as time 
progresses the effect of specific announcements switches in sign while the effect of general announcements remains positive.

\section{[Insert Figure 3, here]}

\section{$\underline{5.2 \text { Cross-area spillover effects of general announcements }}$}

Table 4 presents results of possible cross-area general announcement effects; cf. equation (2). A bank in a given country may respond not only to its country's $G$ and its own $S$, but also to $G$ affecting other banks abroad. To explore this issue, our 116 banks were divided into the three geographical areas of Europe, the Pacific, and the United States. ${ }^{15}$ In the base model (left panel), four of the eight cross-area spillovers are statistically significant at least at the 10 percent level. ${ }^{16}$ Two different patterns emerge: the cross effect of the Pacific area on the United States is negative, but the cross effect of one Pacific country on another Pacific country is positive; the cross effect of the United States on Europe is positive, but the cross effect of one European country on another European country is negative. A positive cross effect is what one would expect in an interconnected world. On the other hand, a negative cross effect is consistent with a view that foreign rescue plans give a competitive advantage to foreign banks. It is also worth noting that the impact of the own $G$ in the United States is at least twice as large as that in Europe and the Pacific area, reflecting the more aggressive and extensive nature of US intervention plans.

The results of the expanded model (right panel), in addition to confirming the results of the base model, show that the own $G$ either reduces or leaves unchanged market risk in Europe and the Pacific area, but raises it in the United States. This indicates that bank interconnectedness runs from Western Europe and the Pacific area to the United States, but not vice versa. The noted US

\footnotetext{
15 We cannot determine cross-country spillovers because of the collinearity of many general announcements across countries.

${ }^{16}$ Note that some other coefficients are only marginally insignificant.
} 
distinctiveness may well reflect US financial leadership in the world, including the special role of the US dollar in the international monetary system.

[Insert Table 4, here]

\section{$\underline{5.3 \text { Cross-bank spillover effects of specific announcements }}$}

Next, we test the cross-bank spillover effects induced by specific announcements. Given the limitations of our data and the particular role of the US financial market, we restrict the test to the 45 US banks in our sample, which are divided in tertiles based on their PRE market capitalization. Also, the data do not permit the use of interactive terms for cross-area and cross-group spillovers. Table 5 shows the estimates of equation (3a). Cross-group effects are negative, suggesting a resource crowding-out phenomenon and the absence of a too-big-to-fail policy: when the government saves a bank, the market fears that the government will curtail subsidies to other banks.

\section{[Insert Table 5 here]}

We probe further into the too-big-to-fail issue by focusing on the largest banks; see Table 6 . We select the top seven US banks by market capitalization as of June 30, 2008: Bank of America, JPMorgan, Citigroup, Wells Fargo, Goldman Sachs, Morgan Stanley and American Express, which account for more than 60 percent of US bank market capitalization, 100 percent of asset and debt guarantees, and 90 percent of capital injections. ${ }^{17}$ The estimation is performed with OLS and robust standard errors. SIZEREL is no longer necessary without the cross-sectional dimension and it is eliminated.

Recall that while a specific announcement may signal unexpected financial difficulties of the targeted institution and inter-bank competition for subsidies, it may also signal the intention of government to save another bank at least as big as the one it just saved. The pattern of cross-bank

\footnotetext{
${ }^{17}$ Bank of America and JP Morgan, had market capitalization of $\$ 147$ and $\$ 140$ billion, respectively; Citigroup and Wells Fargo were approximately two-thirds of their size, Goldman Sachs half of their size, and Morgan Stanley and American Express less than one third of their size. This ranking holds for different dates of market valuations ad is consistent with a ranking based on employment.
} 
spillovers suggests both resource crowding-out and too-big-to-fail effects are present. The inference about the former emerges from negative and statistically significant coefficients in the upper triangle of the XBS matrix of Table 6: Bank of America's announcements penalize the smaller Citigroup and Wells Fargo; similarly, Morgan Stanley's announcements penalize the smaller American Express. Consistent with this pattern is the boost that American Express and Wells Fargo's announcements give to larger Bank of America, Citigroup, and Morgan Stanley, and Morgan Stanley's announcements give to larger Citigroup. However, there are also deviations to this pattern, such as the negative cross-effect of Goldman Sachs's announcements on larger Citigroup and Wells Fargo. In sum, our findings are consistent with a mix of resource crowding-out and too-big-to-fail policy, albeit limited to the largest US banks. We leave open the possibility that too-big-to-fail policy may operate not only on size, but also on the degree of the targeted bank's interconnectedness with other financial institutions.

[Insert Table 6, here]

\subsection{Multiple specific announcements}

Our last test relates to impact on bank returns of multiple specific announcements $(C U M)$. Table 7 reports the estimation of equation (4) after eliminating the dummy $S$ because it is already included in $C U M$. We report on the selection of bank fixed vs. random effect models using the Hausman test. There are two sections in the table: one on the left relates to banks with at least one single specific announcement (CUMI dummy variable) and the other on the right relates to banks with multiple specific announcements broken down by number of interventions (CUM1 and CUM2 dummy variables). ${ }^{18}$ Concerning the former, three important findings emerge. The first is that beta rises when a bank receives a subsidy, suggesting a higher degree of moral hazard or a more fragile banking system. The second is that the benefit of a general announcement declines for banks targeted by a specific

\footnotetext{
${ }^{18}$ CUM1 is equal to one 1 when bank $i$ receives only one specific announcement and zero otherwise, whereas $C U M 2$ is equal to one when bank $i$ receives at least two specific announcements and zero otherwise.
} 
announcement, whose CAR falls by 7.5 percentage points in the United States and 7.2 points in Europe. Furthermore, the interaction of $G$ with $C U M 1$ fails to reduce market risk of targeted banks. The third is that bank size becomes more important for multi-intervention banks in smaller European markets than in the larger US market. This could be interpreted as markets anticipating different reactions by authorities to bank size: too-big-to-fail policy may be more relevant for small than large countries because banks from small countries need to be larger in relation to domestic market size than banks from big countries to compete in global markets. The right panel of Table 7 extends the model to distinguish between the effects of single-S (CUM1) and multi-S banks (CUM2). The key finding here is that US multi-S banks face a higher market risk, whereas their European counterparts are penalized by negative $G$-induced CAR. ${ }^{19}$ On the other hand, abnormal betas increase with the number of public interventions in the United Staates, but not in Europe.

In sum, the findings of Table 7 suggest that the soft budget constraint implied by government subsidies reduces the efficacy of repeated rescue announcements and induces a more opportunistic behavior in targeted banks. Differences between areas affect marginally this result. The diminishing benefits from government interventions have the policy implication that subsidies are only an urgent and temporary crisis measures and should be quickly replaced by structural reforms.

[Insert Table 7, here]

\section{CONCLUSIONS}

The great financial crisis of 2007-2009 had its roots in a credit boom that manifested itself in an extremely indebted US economy. Subprime defaults spread the fire in a financial system that had become fragile as a result of several factors unique to this crisis. Banks' undercapitalization explains the persistence of the crisis and why governments have injected vast sums of public funds into banks.

${ }^{19}$ CAR value is -27 percentage points; see column 6 of Table 7. 
Our paper focuses on the specific question of whether general and specific rescue announcements were priced by the markets as cumulative abnormal returns over selected event windows. General announcements tend to be associated with positive abnormal returns (and lower market risk) and specific announcements with negative abnormal returns (and higher market risk); foreign general announcements exert cross-area spillovers, but are perceived by the home-country banks as subsidies boosting the competitive advantage of foreign banks; specific announcements exert a resource crowding-out effect on other banks; and multiple specific announcements increase the degree of moral hazard of subsidized banks. Our results are also sensitive to the information environment. Specific announcements tend to exert a positive impact on rates of return in the preLehman failure period, when announcements were few and markets trusted the "normal" information flow. The opposite occurred in the turbulent phase of the crisis when announcements were frequent and markets mistrusted the information flow. These results appear consistent with the observed reluctance of individual institutions to request public assistance. The fear of being identified as a "bad apple" was also the reason why some banks were reticent to apply at central banks for emergency lending.

Three other generalizations emerge from our evidence. The first is that market reaction to rescue announcements is not uniform across areas. In particular, capital injections in the United States, the country where the crisis originated and the world's financial leader, exert effects on bank returns that are different from those in other countries. The second is that markets appear to have valued timely and big actions without much regard to refinements as to the type of actions undertaken. The different long-run consequences of different types of interventions were ignored. As it is true in a war, participants in a financial crisis want to survive: planning horizons are shortened and considerations that are taken seriously under normal circumstances are instead relegated in the background. This pattern is consistent with the lessons from the last Nordic and Japanese banking crises: timely and big 
public interventions solved successfully the crisis in Sweden, whereas untimely and small government measures led to the lost Japanese decade. It is also consistent with the diminishing benefits from government interventions that reinforce markets' perceptions that subsidies are urgent and temporary anti-crisis measures and should be quickly replaced by structural reforms. The third is that, given that different announcements produce similar effects, governments might have had incentives to gamble for opaque and "low-cost" guarantees of bank assets and debts rather than undertake more transparent and costly alternatives.

Government rescue plans are likely to lead to a consolidation of the banking system. This, in turn, raises the probability of invoking the too-big-to-fail policy. We find that bank size matters even if there is not a clear evidence for the too-big-to-fail policy. In one test dealing with cross-bank spillovers using the largest US banks, our findings are consistent with a mix of resource crowding-out and toobig-to-fail policy. Clues about the latter also emerge from multiple-event regressions by area. The resolution of this issue remains unsettled in part because the too-big-to-fail policy may operate not only on size, but also on the degree of the targeted bank's interconnectedness with other financial institutions.

\section{Acknowledgements}

We thank Matteo Cassiani for providing us with bank data and Angelo Baglioni and Luca Papi for comments and suggestions on an earlier version of the paper.

\section{References}

Adrian, T., Shin, H.S., 2008. Liquidity and leverage. Federal Reserve Bank of New York available online at http://www.newyorkfed.org/research/staff_reports/sr328.html.

Ball, R., Brown, P., 1968. An Empirical Evaluation of Accounting Income Numbers. Journal of Accounting Research, 6(2):159-78. 
Binder, J.J., 1998. The event study methodology since 1969. Review of Quantitative Finance and Accounting, 11:111-137.

BNP Paribas, 2009. To the rescue. Report of Market Economics, Interest Rate Strategy, Credit Strategy

Calomiris, C.W., 2007. Not (yet) a 'Minsky’ moment. Unpublished paper (October 5).

CNN Money, online. http://money.cnn.com/news/specials/storysupplement/bankbailout/.

Corrado, C.J., 2009. Event Studies: A Methodology Review. Available at SSRN: http://ssrn.com/abstract=1441581.

De Jong, F., 2007. Event Studies Methodology. Lecture Notes.

Dell'Ariccia, G., Egan, D., Laeven, L., 2008. Credit booms and lending standards: Evidence from the subprime mortgage market. International Monetary Fund, Working Paper, WP/08/106.

Demyanyk, Y., van Hemert, O., 2009. Understanding the subprime mortgage crisis. Review of Financial Studies, RFS Advance Access published online, doi:10.1093/rfs/hhp033

DLA Piper, online. http://www.dlapiper.com/it/austria/news/detail.aspx ?news=2858.

Dolley, J.C., 1933. Characteristics and Procedure of Common Stock Split-Ups. Harvard Business Review, 11:316-26.

Fama, E., Fisher, L., Jensen, M., Roll, R., 1969. The adjustment of stock prices to new information. International Economic Review, 10:1-21.

Federal Reserve Bank of St. Louis, online. The Financial Crisis: A Timeline of Events and Policy Actions. Available online at http://timeline.stlouisfed.org/index.cfm?p=timeline\#.

Fisher, I., 1933. The Debt Deflation Theory of Great Depressions. Econometrica, 1; 337-57.

Fratianni, M., 2008. Financial crises, safety nets and regulation. Rivista Italiana degli Economisti, 2: 169-208.

Fratianni, M., Marchionne, F., 2009. The role of banks in the subprime financial crisis. Review of Economic Conditions in Italy, 2009/1:11-48.

Glauber, R.R., 2000. Discussions of the financial crisis. In: Mikitani, R., Posen, A.S. (Eds), Japan's Financial Crisis and Its Parallels to U.S. Experience, Washington, DC, Institute for International Economics, 101-105.

International Capital Market Association, online. http://www.icmagroup.org/getdoc/d084024f-e70946e3-97a6-0b471db7a7ea/Responses-to-market-turbulence--Country-plans.aspx\#Australia.

International Monetary Fund, 2008a. Global financial stability report: Containing systemic risks and restoring financial soundness, April 2008. Washington, DC.

International Monetary Fund, 2008b. Global financial stability report: financial stress and deleveraging, macrofinancial implications and policy, October 2008. Washington, DC. 
Kothari, S.P., Warner, J.B., 2006. Econometrics of Event Studies. In: Eckbo. B.E. (Ed.), Handbook of Corporate Finance: Empirical Corporate Finance, Volume A (Handbooks in Finance Series, Elsevier/North-Holland), Ch. 1.

Kindleberger, C.P., 1978 [2000]. Manias, Panics, and Crashes: A History of Financial Crises. $4^{\text {th }}$ edition, New York: Wiley.

Kothari, S.P., Warner, J.B., 1997. Measuring long-horizon security price performance. Journal of Financial Economics, 43:301-339.

MacKinlay, A.C., 1997. Event Studies in Economics and Finance. Journal of Economic Literature, 35(1):13-39.

Mediobanca, 2009. Sintesi dei principali piani di stabilizzazione finanziaria in Europe e negli Stati Uniti, Aggiornamento al 5 giugno 2009. Ricerche e Studi.

Meulbroek, L.K., 1992. An Empirical Analysis of Illegal Insider Trading. Journal of Finance 47(5):1661-1699.

Minsky, H., 1977. A Theory of Systemic Fragility. In: E. J. Altman and A. W. Sametz (eds). Financial Crises: Institutions and Markets in a Fragile Environment. New York. Wiley, 138-52.

Mitchell, W.C., 1913. Business Cycles. New York: Burt Franklin.

O'Hara, M., Shaw, W., 1990. Deposit Insurance and Wealth Effects: The Value of Being "Too Big to Fail”. Journal of Finance, 45(5):1587-1600.

Panetta, F., Faeh, T., Grande, G., Ho, C., King, M., Levy, A., Signoretti, F.M., Taboga, M., Zaghini, A., 2009. An assessment of financial sector rescue programmes. BIS Paper, 48; http://www.bis.org/.

Serra, A.P., 2002. Event Study Tests: A Brief Survey. FEP Working Paper n.117. 
Figure 1: TED spread and TED-equivalent spreads, various countries.
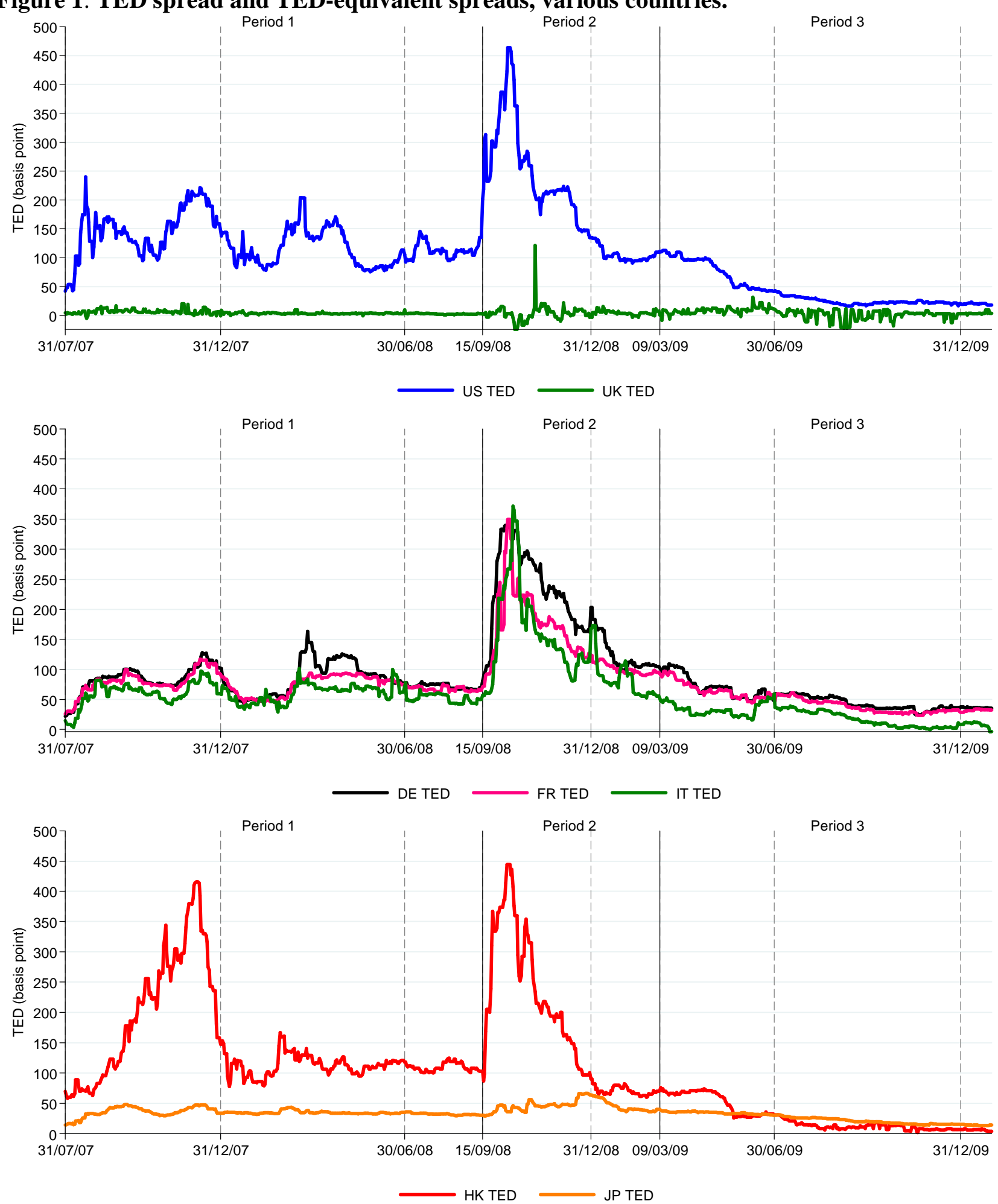

NOTES: TED spread is the difference between the three-month dollar LIBOR and the three-month T-bill interest rate (US); TED-equivalent spreads are those of the United Kingdom (UK), Honk-Kong (HK), Japan (JP), Germany (DE), France (FR) and Italy (IT). Source: Bloomberg (February 14, 2010). 
Figure 2: Cumulative value of general announcements in US\$ billion, September 28, 2008October 18, 2008.

$\square$ Cumulative Capital Injection $\square$ Cumulative As set and Debt Guarantees

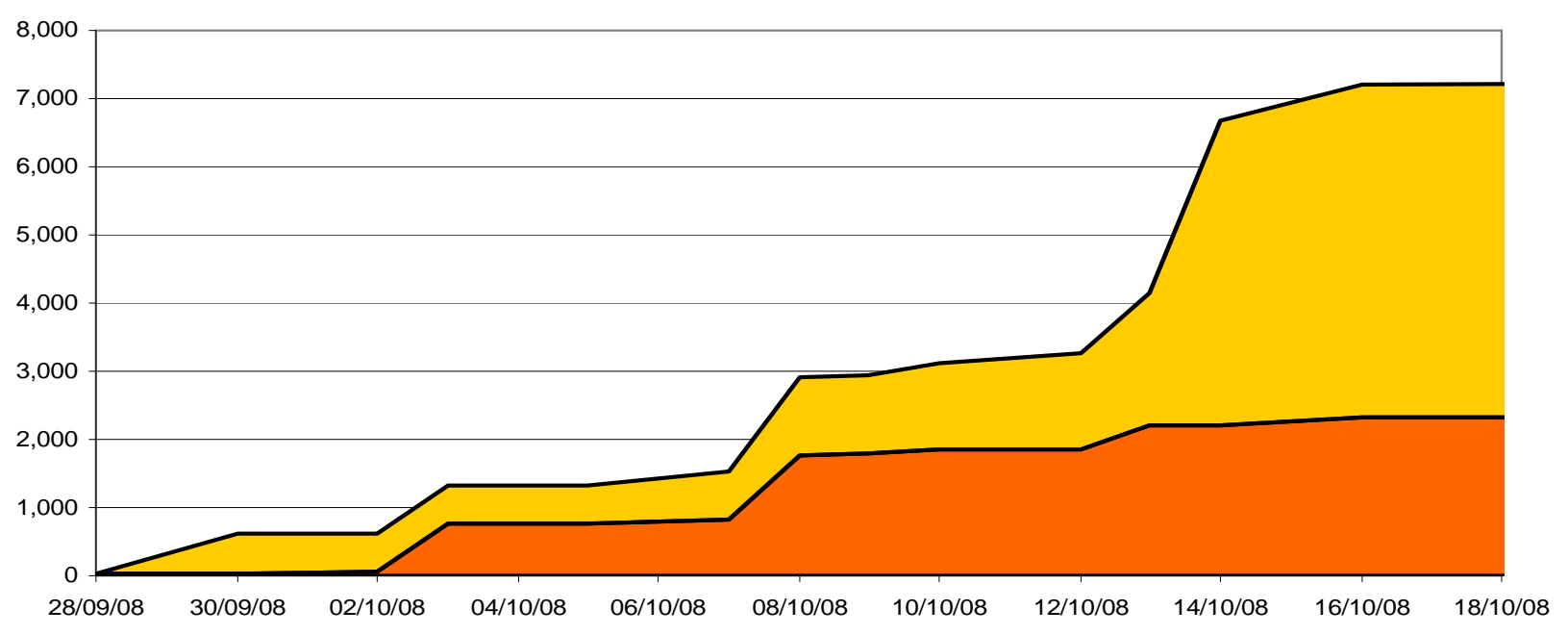


Figure 3: Recursive rolling coefficients, estimation window from July 31, 2007 to July 31, 2008.
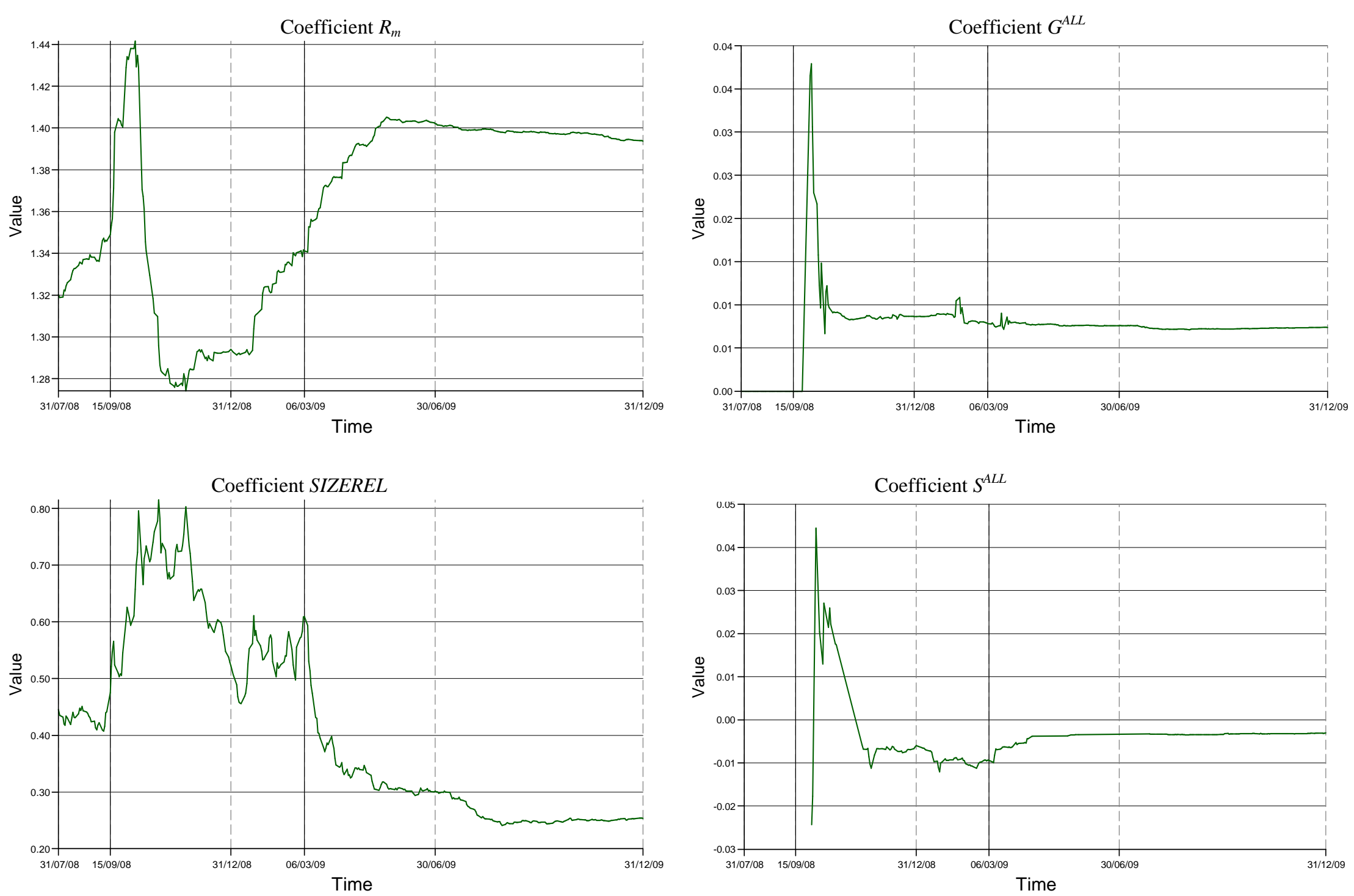
Table 1: Rates of returns in local currency and in dollars of a sample of US, European and Pacific region banks, in percent, July 31, 2007- December 31, 2009.

\begin{tabular}{|l|l|rrr|rrr|rrr|}
\hline Area & Country & \multicolumn{2}{|c|}{$31 / 07 / 2007$} & $15 / 09 / 2008$ & \multicolumn{2}{|c|}{$31 / 07 / 2007$} & $09 / 03 / 2009$ & \multicolumn{3}{|c|}{$31 / 07 / 200731 / 12 / 2009$} \\
& & LCU & EXC & USD & LCU & EXC & USD & LCU & EXC & USD \\
\hline Europe & AT & -37.50 & 3.38 & -35.38 & -86.11 & -7.84 & -87.20 & -60.89 & 4.53 & -59.12 \\
& BE & -39.02 & 3.38 & -36.96 & -93.43 & -7.84 & -93.95 & -70.28 & 4.53 & -68.94 \\
& DE & -46.53 & 3.38 & -44.72 & -91.83 & -7.84 & -92.47 & -77.40 & 4.53 & -76.38 \\
& EI & -60.99 & 3.38 & -59.67 & -98.13 & -7.84 & -98.28 & -93.77 & 4.53 & -93.48 \\
& ES & -36.89 & 3.38 & -34.75 & -64.25 & -7.84 & -67.05 & -38.00 & 4.53 & -35.19 \\
& FR & -43.49 & 3.38 & -41.58 & -79.75 & -7.84 & -81.34 & -47.36 & 4.53 & -44.98 \\
& GR & -31.57 & 3.38 & -29.26 & -71.15 & -7.84 & -73.41 & -52.38 & 4.53 & -50.23 \\
& IT & -33.13 & 3.38 & -30.87 & -72.84 & -7.84 & -74.97 & -54.14 & 4.53 & -52.07 \\
& NL & -37.08 & 3.38 & -34.95 & -90.53 & -7.84 & -91.27 & -72.46 & 4.53 & -71.21 \\
& PT & -59.21 & 3.38 & -57.83 & -76.57 & -7.84 & -78.40 & -63.65 & 4.53 & -62.00 \\
& CH & 14.07 & 7.38 & 22.49 & 15.35 & 3.32 & 19.18 & 17.56 & 16.05 & 36.43 \\
& DK & -41.00 & 3.20 & -39.11 & -80.81 & -7.92 & -82.33 & -50.20 & 4.50 & -47.96 \\
& NO & -30.50 & 0.46 & -30.17 & -72.32 & -17.77 & -77.24 & -14.95 & 0.29 & -14.70 \\
& SE & -39.05 & -0.60 & -39.42 & -72.78 & -26.26 & -79.93 & -34.96 & -6.11 & -38.93 \\
& UK & -28.75 & -12.21 & -37.45 & -68.62 & -32.44 & -78.80 & -28.31 & -20.61 & -43.09 \\
\hline
\end{tabular}

NOTES: $\mathrm{LCU}=$ rate of return in local-currency units; EXC = depreciation (-)/appreciation (+) of the US dollar relative to the local currency; USD = rate of return in dollars; $\mathrm{AT}=$ Austria; $\mathrm{BE}=$ Belgium; $\mathrm{CH}=\mathrm{Switzerland}$; $\mathrm{DE}=\mathrm{Germany}$; $\mathrm{DK}=$ Denmark; EI=Eire; ES=Spain; FR=France; GR=Greece; IT=Italy; NO=Norway; NL=Netherlands; PT=Portugal; $\mathrm{SE}=$ Sweden; UK=United Kingdom; AU=Australia; HK=Hong-Kong; JP=Japan; US=United States. CME Group Inc., Discover Financial Services, Fukuoka Financial Group, and Invesco Ltd were excluded from the sample of 122 banks because they did not make the list at the end of July 2007. As CIT Group filed for Chapter 11 bankruptcy protection, it is excluded from November 2009.

Source: Bloomberg (February 14, 2010). 
Table 2: Descriptive statistics

Pre-Lehman failure period (31/07/2007-14/09/2008): 33,610 obs.

\begin{tabular}{lrr|rrrrr}
\hline Variable & \multicolumn{1}{c|}{ Mean } & \multicolumn{1}{c|}{ S.D. } & \multicolumn{1}{c}{ Min } & \multicolumn{1}{c}{ Q1 } & \multicolumn{1}{c}{ Median } & \multicolumn{1}{c}{ Q3 } & \multicolumn{1}{c}{ Max } \\
\hline$R_{i}$ & $-0.09 \%$ & $3.04 \%$ & $-58.67 \%$ & $-1.71 \%$ & $-0.11 \%$ & $1.34 \%$ & $40.85 \%$ \\
$R_{m}$ & $-0.07 \%$ & $1.51 \%$ & $-8.65 \%$ & $-0.95 \%$ & $0.00 \%$ & $0.76 \%$ & $10.72 \%$ \\
SIZE $_{i}$ & 33,287 & 45,319 & 956 & 7,055 & 15,353 & 40,459 & 320,147 \\
SIZE $_{m}$ & $4,235,453$ & 444,594 & $2,610,880$ & $3,901,534$ & $4,246,899$ & $4,594,350$ & $5,132,827$ \\
SIZEREL & $0.79 \%$ & $1.07 \%$ & $0.02 \%$ & $0.17 \%$ & $0.37 \%$ & $0.98 \%$ & $8.38 \%$ \\
\hline
\end{tabular}

Post-Lehman failure period (15/09/2008-31/12/2009): 38,760 obs.

\begin{tabular}{lrr|rrrrr}
\hline Variable & \multicolumn{1}{c}{ Mean } & \multicolumn{1}{c}{ S.D. } & \multicolumn{1}{c}{ Min } & \multicolumn{1}{c}{ Q1 } & \multicolumn{1}{c}{ Median } & \multicolumn{1}{c}{ Q3 } & \multicolumn{1}{c}{ Max } \\
\hline$R_{i}$ & $0.03 \%$ & $5.36 \%$ & $-75.15 \%$ & $-2.20 \%$ & $0.00 \%$ & $2.03 \%$ & $86.98 \%$ \\
$R_{m}$ & $0.00 \%$ & $2.46 \%$ & $-13.03 \%$ & $-1.11 \%$ & $0.04 \%$ & $1.15 \%$ & $14.35 \%$ \\
SIZE $_{i}$ & 21,802 & 36,192 & 98 & 3,780 & 7,463 & 22,183 & 302,481 \\
SIZE $_{m}$ & $2,791,859$ & 738,404 & $1,314,889$ & $2,188,021$ & $2,694,310$ & $3,551,743$ & $3,950,598$ \\
SIZEREL & $0.78 \%$ & $1.25 \%$ & $0.00 \%$ & $0.15 \%$ & $0.28 \%$ & $0.86 \%$ & $9.83 \%$ \\
\hline
\end{tabular}

\section{LEGEND}

\begin{tabular}{lll}
\hline \multicolumn{1}{c}{ Name } & \multicolumn{1}{c}{ Formula } & \multicolumn{1}{c}{ Description } \\
$R_{i}$ & $=\frac{P X_{i, t}-P X_{i, t-1}}{P X_{i, t-1}}$ & $\begin{array}{l}\text { Daily rate of return of the bank } i(P X=\text { stock price in local current } \\
\text { unit) }\end{array}$ \\
$R_{m}$ & $=\frac{P X_{m, t}-P X_{m, t-1}}{P X_{m, t-1}}$ & $\begin{array}{l}\text { Daily rate of return of the national stock exchange where bank } i \text { is } \\
\text { located }(P X=\text { stock index })\end{array}$ \\
$S I Z E_{i}$ & $=P X_{i, t} \cdot S h_{i, t} \cdot D E X_{i, t}$ & $\begin{array}{l}\text { Daily market capitalization of bank } i \text { ( } P X=\text { stock price in local } \\
\text { current unit; } S h=\text { number of share; } D E X=\text { Daily exchange rate })\end{array}$ \\
$S I Z E_{m}$ & $=\sum_{i=1}^{122} S I Z E_{i} \quad i \notin U K$ & $\begin{array}{l}\text { Daily market capitalization of all banks in the sample excluded } \\
\text { UK banks }\end{array}$ \\
$S I Z E R E L$ & $=\frac{S I Z E_{i, t}}{S I Z E_{m, t}}$ & Relative market capitalization of bank $i$
\end{tabular}


Table 3: Effects of general and specific announcements on banks' rates of return.

\begin{tabular}{|c|c|c|c|c|c|c|c|c|c|}
\hline \multirow[b]{2}{*}{ VARIABLES } & \multicolumn{4}{|c|}{ All Announcements } & \multicolumn{5}{|c|}{ Announcements by type } \\
\hline & $\begin{array}{c}\text { WORLD PRE } \\
\text { (1) }\end{array}$ & $\begin{array}{c}\text { WORLD POST } \\
\text { (2) }\end{array}$ & $\begin{array}{c}\text { WORLD POST } \\
\text { (3) }\end{array}$ & $\begin{array}{c}\text { WORLD POST } \\
\text { (4) }\end{array}$ & $\begin{array}{c}\text { WORLD POST } \\
\text { (5) }\end{array}$ & $\begin{array}{c}\text { WORLD POST } \\
(6)\end{array}$ & $\begin{array}{c}\text { USA POST } \\
(7)\end{array}$ & $\begin{array}{c}\text { EUROPE POST } \\
(8)\end{array}$ & $\begin{array}{c}\text { PACIFIC POST } \\
(9)\end{array}$ \\
\hline Constant & $-0.00342^{* * *}$ & $-0.00471 * * *$ & $-0.00470 * * *$ & $-0.00476 * * *$ & $-0.00472 * * *$ & $-0.00471^{* * *}$ & $-0.00516^{* * *}$ & $-0.00614 * * *$ & $-0.00366^{* * *}$ \\
\hline$R_{m}$ & $1.346^{* * *}$ & $1.409^{* * *}$ & $1.418^{* * *}$ & $1.418 * * *$ & $1.409^{* * *}$ & $1.422 * * *$ & $1.818^{* * *}$ & $1.283^{* * *}$ & $1.048^{* * *}$ \\
\hline SIZEREL & $0.441 * * *$ & $0.581 * * *$ & $0.579 * * *$ & $0.588 * * *$ & $0.581 * * *$ & $0.581 * * *$ & $0.765 * * *$ & $1.195 * * *$ & $0.210 * * *$ \\
\hline$G^{A L L}$ & & $0.00745 * * *$ & $0.00725 * * *$ & $0.00781 * * *$ & & & & & \\
\hline$R_{m} * G^{A L L}$ & & & $-0.0720 * * *$ & $-0.0714 * * *$ & & & & & \\
\hline$S I Z E R E L * G^{A L L}$ & & & & -0.0756 & & & & & \\
\hline$G^{C A P}$ & & & & & $0.00758^{* * * *}$ & $0.00812 * * *$ & $0.0112^{* * *}$ & 0.00220 & $0.00655^{* * *}$ \\
\hline$R_{m} * G^{C A P}$ & & & & & & $0.262 * * *$ & $0.421 * * *$ & $-0.103 * *$ & 0.0138 \\
\hline$G^{G U A}$ & & & & & $0.00288^{*}$ & 0.000994 & 0.00425 & $-0.00330 \#$ & $0.00634 * * *$ \\
\hline$R_{m} * G^{G U A}$ & & & & & & $-0.552 * * *$ & $-1.128 * * *$ & $-0.140 * * *$ & -0.0312 \\
\hline$S^{A L L}$ & $0.0177 *$ & $-0.00347 * *$ & $-0.00351 * *$ & -0.00293 & & & & & \\
\hline$R_{m} * S^{A L L}$ & & & $0.123 * *$ & $0.125 * *$ & & & & & \\
\hline SIZEREL* $S^{A L L}$ & & & & -0.0642 & & & & & \\
\hline$S^{C A P}$ & & & & & $-0.00471 * *$ & $-0.00491 * *$ & $-0.00582 *$ & $-0.00384 \#$ & - \\
\hline$R_{m} * S^{C A P}$ & & & & & & $0.136 * *$ & $-0.398 * * *$ & $0.515 * * *$ & - \\
\hline$S^{G U A}$ & & & & & 0.000896 & 0.00103 & 0.0138 & $-4.13 e-05$ & - \\
\hline$R_{m} * S^{G U A}$ & & & & & & $0.383 * * *$ & $1.725 * * *$ & $0.249 * *$ & - \\
\hline Observations & 33,189 & 38,745 & 38,745 & 38,745 & 38,745 & 38,745 & 15,060 & 15,065 & 8,620 \\
\hline $\mathrm{R}^{2}$ & 0.447 & 0.420 & 0.420 & 0.420 & 0.420 & 0.424 & 0.435 & 0.433 & 0.562 \\
\hline Number of bank & 116 & 116 & 116 & 116 & 116 & 116 & 45 & 45 & 26 \\
\hline WALD Test (Prob > F) & 0.0831 & 0 & 0 & 0 & 0 & 0 & 0 & 0 & 0 \\
\hline Hausman Test (Prob > chi2) & 0 & 0 & 0 & 0 & 0 & 0 & 0.0329 & 0.00250 & 0.0649 \\
\hline SIZEREL (mean) & $0.347 \%$ & $0.456 \%$ & $0.454 \%$ & $0.461 \%$ & $0.456 \%$ & $0.456 \%$ & $0.600 \%$ & $0.937 \%$ & $0.165 \%$ \\
\hline Q1=Hypo Real Estate & $0.068 \%$ & $0.028 \%$ & $0.028 \%$ & $0.029 \%$ & $0.028 \%$ & $0.028 \%$ & & & \\
\hline Q2=Banca Monte dei Paschi di Siena & $0.174 \%$ & $0.262 \%$ & $0.261 \%$ & $0.265 \%$ & $0.262 \%$ & $0.262 \%$ & & & \\
\hline Q3=Bank of New York Mellon & $0.488 \%$ & $0.721 \%$ & $0.719 \%$ & $0.730 \%$ & $0.721 \%$ & $0.721 \%$ & & & \\
\hline $\mathrm{CAR}=G^{A L L} * 7$ & & $5.215 \%$ & $5.075 \%$ & $5.467 \%$ & & & & & \\
\hline $\mathrm{CAR}=G^{C A P} * 7$ & & & & & $5.306 \%$ & $5.684 \%$ & $7.840 \%$ & - & $4.585 \%$ \\
\hline $\mathrm{CAR}=G^{G U A} * 7$ & & & & & $2.016 \%$ & - & - & $-2.310 \%$ & $4.438 \%$ \\
\hline $\mathrm{CAR}=S^{A L L_{* 5}}$ & $8.850 \%$ & $-1.735 \%$ & $-1.755 \%$ & - & & & & & \\
\hline $\mathrm{CAR}=S^{C A P * 5}$ & & & & & $-2.355 \%$ & $-2.455 \%$ & $-2.910 \%$ & $-1.920 \%$ & - \\
\hline $\mathrm{CAR}=S^{G U A * 5}$ & 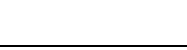 & & & & - & - & - & - & - \\
\hline
\end{tabular}


Table 4: Cross-area effects of general announcements on banks' rates of return, POST period.

\begin{tabular}{|c|c|c|c|c|c|c|}
\hline \multirow{3}{*}{ VARIABLES AREA } & \multicolumn{3}{|c|}{ Base Model } & \multicolumn{3}{|c|}{ Expanded Model } \\
\hline & USA & EUROPE & PACIFIC & USA & EUROPE & PACIFIC \\
\hline & $(1)$ & $(2)$ & (3) & (4) & (5) & (6) \\
\hline Constant & $-0.00498 * * *$ & $-0.00460 * * *$ & $-0.00392 * * *$ & $-0.00545 * * *$ & $-0.00461 * * *$ & $-0.00382 * * *$ \\
\hline$R_{m}$ & $1.752 * * *$ & $1.256^{* * *}$ & $1.049 * * *$ & $2.072 * * *$ & $1.378 * * *$ & $1.084 * * *$ \\
\hline SIZEREL & $0.751 * * *$ & $1.035^{* * * *}$ & $0.221 * * *$ & $0.762 * * *$ & $1.011 * * *$ & $0.210 * * *$ \\
\hline$G^{A L L}$ & $0.0130 * * *$ & -0.000241 & $0.00551 * * *$ & $0.0115 * * *$ & -0.000276 & $0.00549 * * *$ \\
\hline$R_{m} * G^{A L L}$ & & & & $0.121 * *$ & $-0.0793 * *$ & 0.00425 \\
\hline$S^{A L L}$ & $-0.00515^{*}$ & -0.000702 & & $-0.00525^{*}$ & -0.000826 & \\
\hline$R_{m} * S^{A L L}$ & & & & $-0.304 * * *$ & $0.368 * * *$ & \\
\hline$X A G_{U S A}$ & & $0.00773 * * *$ & $0.00174 \#$ & & $0.00699 * * *$ & $0.00153 \#$ \\
\hline$R_{m} * X A G_{U S A}$ & & & & & $0.105 * *$ & $0.0859 * *$ \\
\hline$X A G_{E U R O P E}$ & 0.000469 & $-0.00464 * * *$ & $-0.000879 \#$ & 0.000990 & $-0.00466 * * *$ & -0.000739 \\
\hline$R_{m} * X A G_{E U R O P E}$ & & & & $-0.378 * * *$ & $-0.181 * * *$ & $-0.0677 * * *$ \\
\hline$X A G_{P A C I F I C}$ & $-0.00280 *$ & $-0.00143 \#$ & $0.00343 * * *$ & -0.00177 & $-0.00153 \#$ & $0.00355^{* * *}$ \\
\hline$R_{m} * X A G_{\text {PACIFIC }}$ & & & & $-0.472 * * *$ & $-0.201 * * *$ & $-0.0626 \#$ \\
\hline Observations & 15,060 & 15,065 & 8,620 & 15,060 & 15,065 & 8,620 \\
\hline $\mathrm{R}^{2}$ & 0.423 & 0.433 & 0.563 & 0.431 & 0.438 & 0.563 \\
\hline Number of bank & 45 & 45 & 26 & 45 & 45 & 26 \\
\hline WALD Test $($ Prob > F) & 0.130 & 0 & 0.000200 & 0 & 0 & 0 \\
\hline Hausman Test (Prob > chi2) & 0.00620 & 0.00540 & 0.0873 & 0.0441 & 0.0513 & 0.429 \\
\hline $\mathrm{CAR}=X A G_{U S A} * 7$ & & $5.411 \%$ & $1.218 \%$ & & $4.893 \%$ & $1.071 \%$ \\
\hline $\mathrm{CAR}=X A G_{E U R O P E} * 7$ & - & $-3.248 \%$ & $-0.609 \%$ & - & $-3.262 \%$ & - \\
\hline $\mathrm{CAR}=X A G_{\text {PACIFIC }} * 7$ & $-1.960 \%$ & $-1.001 \%$ & $2.401 \%$ & - & $-1.071 \%$ & $2.485 \%$ \\
\hline
\end{tabular}

NOTES: POST $=15 / 09 / 2008$ to 31/12/2009. $R_{m}=$ daily rate of return of the national stock exchange where bank $i$ is located; SIZEREL $=$ relative market capitalization of bank $i$; $G(S)=$ general (specific) announcement dummy; $A L L=$ all announcement types (capital injections and asset and debt guarantees). $X A G_{x}=$ cross-area general announcement from multi-country $x$ area: it excludes bank $i$ 's home country announcements. CAR = cumulative abnormal returns with 7 day windows. All estimations include bank fixed effects; UK banks excluded. WALD vs null cross-area general announcement effects; Hausman Test vs random effects. *** $\mathrm{p}<0.01 * * \mathrm{p}<0.05 * \mathrm{p}<0.10 \# \mathrm{p}<0.15$. 
Table 5: Cross-bank effects of specific announcements on banks' rates of return; POST period.

\begin{tabular}{|c|c|c|c|c|c|c|}
\hline \multirow[b]{2}{*}{ VARIABLES } & \multicolumn{3}{|c|}{ Base Model } & \multicolumn{3}{|c|}{ Expanded Model } \\
\hline & $\begin{array}{c}1^{\mathrm{ST}} \text { Tertile } \\
\text { USA } \\
(1)\end{array}$ & $\begin{array}{c}2^{\mathrm{ND}} \text { Tertile } \\
\text { USA } \\
(2)\end{array}$ & $\begin{array}{c}3^{\mathrm{RD}} \text { Tertile } \\
\text { USA } \\
(3)\end{array}$ & $\begin{array}{c}1^{\text {ST }} \text { Tertile } \\
\text { USA } \\
(4)\end{array}$ & $\begin{array}{c}2^{\mathrm{ND}} \text { Tertile } \\
\text { USA } \\
(5)\end{array}$ & $\begin{array}{c}3^{\mathrm{RD}} \text { Tertile } \\
\text { USA } \\
(6)^{\mathrm{a}}\end{array}$ \\
\hline Constant & $-0.0107 * * *$ & $-0.0144 * * *$ & $-0.00852 * * *$ & $-0.0107 * * *$ & $-0.0144 * * *$ & $-0.00854 * * *$ \\
\hline$R_{m}$ & $1.702 * * *$ & $1.720 * * *$ & $1.821 * * *$ & $1.779 * * *$ & $1.790 * * *$ & $1.883 * * *$ \\
\hline SIZEREL & $9.241 * * *$ & $4.941 * * *$ & $0.613 * * *$ & $9.313 * * *$ & $4.972 * * *$ & $0.613 * * *$ \\
\hline$G^{A L L}$ & $0.0142 * * *$ & $0.0132 * * *$ & $0.0101 * * *$ & $0.0137 * * *$ & $0.0128 * * *$ & $0.00973^{* * *}$ \\
\hline$R_{m} * G^{A L L}$ & & & & $-0.293 * * *$ & $-0.244 * * *$ & $-0.200 * * *$ \\
\hline$S^{A L L}$ & 0.00521 & 0.00966 & -0.00515 & 0.00310 & 0.00782 & -0.00487 \\
\hline$R_{m} * S^{A L L}$ & & & & $-0.576^{* *}$ & $-0.555 * * *$ & $-0.217 * *$ \\
\hline$X A G_{E U R O P E}$ & -0.00313 & 0.000857 & 0.000280 & -0.00331 & 0.000706 & 0.000293 \\
\hline$X A G_{P A C I F I C}$ & -0.00139 & $-0.00515 * *$ & $-0.00386^{*}$ & -0.00124 & $-0.00515 * *$ & $-0.00381 *$ \\
\hline XBS $1^{S T}$ Tertile & $-0.00532 * *$ & $-0.00658 * * *$ & $-0.00335^{*}$ & $-0.00517 * *$ & $-0.00658 * * *$ & $-0.00332 *$ \\
\hline$X B S 2^{N D}$ Tertile & 0.00119 & 0.00311 & 0.00304 & 0.000890 & 0.00303 & 0.00294 \\
\hline$X B S 3^{R D}$ Tertile & 0.000947 & 0.000072 & $-0.00133 * *$ & 0.000879 & 0.000025 & $-0.00130 * *$ \\
\hline Observations & 5,010 & 5,025 & 5,025 & 5,010 & 5,025 & 5,025 \\
\hline $\mathrm{R}^{2}$ & 0.338 & 0.474 & 0.492 & 0.340 & 0.477 & 0.493 \\
\hline Number of bank & 15 & 15 & 15 & 15 & 15 & 15 \\
\hline F-Test $($ Prob $>$ F) & 0 & 0 & 0 & 0 & 0 & 0 \\
\hline WALD Test (Prob > chi2) & 0 & 0 & 0 & 0 & 0 & 0 \\
\hline Hausman Test (Prob > chi2) & 0.00700 & 0.000500 & 0.0944 & 0.0317 & 0.00200 & 0.138 \\
\hline $\mathrm{CAR}=X G S 1^{S T}$ Tertile $^{* 5}$ & $-2.660 \%$ & $-3.290 \%$ & $-1.675 \%$ & $-2.585 \%$ & $-3.290 \%$ & $-1.660 \%$ \\
\hline $\mathrm{CAR}=X G S 2^{N D}$ Tertile $^{* 5}$ & - & - & - & - & - & - \\
\hline $\mathrm{CAR}=X G S 3^{R D}$ Tertile $^{*} 5$ & - & - & $-0.665 \%$ & - & - & $-0.650 \%$ \\
\hline
\end{tabular}

NOTES: POST $=15 / 09 / 2008$ to $31 / 12 / 2009 ; R_{m}=$ daily rate of return of the national stock exchange where bank $i$ is located; SIZEREL $=$ relative market capitalization of bank $i ; G(S)=$ general (specific) announcement dummy; $A L L=$ all announcement types (capital injections and asset and debt guarantees). $X A G_{x}=$ cross-area general announcement from $x . X B S X^{T H}$ group $=$ cross-group specific announcement from $x^{\text {th }}$ group. $X B S$ on itself excludes bank $i$ 's announcements. CAR = cumulative abnormal returns with 5-day windows. All estimations include bank fixed effects; UK banks excluded. WALD vs null cross-group specific announcement effects; Hausman Test vs random effects. $* * * \mathrm{p}<0.01 * * \mathrm{p}<0.05 * \mathrm{p}<0.10 \# \mathrm{p}<0.15$. 
Table 6: Cross-bank specific announcements on banks' rates of return; top seven US banks; POST period.

\begin{tabular}{|c|c|c|c|c|c|c|c|}
\hline VARIABLES & $\begin{array}{c}\text { BANK OF } \\
\text { AMERICA } \\
\text { (1) }\end{array}$ & $\begin{array}{l}\text { JP MORGAN } \\
(2)\end{array}$ & $\begin{array}{l}\text { CITIGROUP } \\
\text { (3) }\end{array}$ & $\begin{array}{c}\text { WELLS } \\
\text { FARGO } \\
(4)\end{array}$ & $\begin{array}{l}\text { GOLDMAN } \\
\text { SACHS } \\
(5)\end{array}$ & $\begin{array}{c}\text { MORGAN } \\
\text { STANLEY } \\
(6) \\
\end{array}$ & $\begin{array}{c}\text { AMERICAN } \\
\text { EXPRESS } \\
(7)\end{array}$ \\
\hline Constant & 0.000870 & 0.00102 & -0.00138 & 0.00161 & 0.00135 & -0.000502 & 0.00319 \\
\hline$R m$ & $2.251 * * *$ & $1.764 * * *$ & $2.187 * * *$ & $1.855^{* * *} *$ & $1.501 * * *$ & $2.546^{* * *}$ & $1.665 * * *$ \\
\hline$G^{A L L}$ & 0.0185 & 0.00714 & 0.0107 & 0.00182 & 0.00641 & 0.0124 & 0.00318 \\
\hline$S^{A L L}$ & $-0.0408 * *$ & 0.00634 & -0.00161 & $0.0313^{*}$ & -0.0244 & -0.0134 & -0.00267 \\
\hline$X A G_{E U R O P E}$ & 0.00277 & 0.00670 & -0.00395 & 0.00327 & 0.00183 & 0.0137 & -0.00306 \\
\hline$X A G_{P A C I F I C}$ & -0.00804 & -0.000623 & 0.00732 & 0.00371 & 0.00749 & 0.00336 & -0.00912 \\
\hline$X B S_{B A N K}$ OF AMERICA & & -0.0141 & $-0.0418 * *$ & $-0.0235^{*}$ & -0.00986 & -0.00924 & -0.00736 \\
\hline$X B S_{J P M O R G A N}$ & 0.00332 & & -0.00845 & 0.00905 & -0.0141 & -0.0121 & 0.0148 \\
\hline$X B S_{\text {CITIGROUP }}$ & -0.00584 & -0.0164 & & -0.0104 & 0.00612 & -0.00342 & 0.000906 \\
\hline$X B S_{\text {WELLS FARGO }}$ & $0.0506^{* *}$ & 0.0182 & $0.0588 * * *$ & & 0.00959 & 0.0103 & 0.0111 \\
\hline$X B S_{\text {GOLDMAN SACHS }}$ & -0.0326 & -0.0189 & $-0.0542 * *$ & $-0.0317 *$ & & -0.0265 & -0.00510 \\
\hline$X B S_{M O R G A N ~ S T A N L E Y}$ & 0.0126 & 0.00789 & $0.0423^{*}$ & 0.00332 & -0.00703 & & $-0.0118^{*}$ \\
\hline$X B S_{\text {AMERICA EXPRESS }}$ & $0.0229 *$ & 0.00667 & 0.0292 & 0.0134 & -0.00149 & $0.0178^{*}$ & \\
\hline Observations & 335 & 335 & 335 & 335 & 335 & 335 & 335 \\
\hline $\mathrm{R}^{2}$ & 0.518 & 0.585 & 0.420 & 0.502 & 0.570 & 0.576 & 0.661 \\
\hline F Test $($ Prob $>$ F) & 0 & 0 & 0 & 0 & 0 & 0 & 0 \\
\hline WALD Test (Prob > F) & 0.0766 & 0.0888 & 0.0119 & 0.131 & 0.612 & 0.281 & 0.549 \\
\hline $\mathrm{CAR}_{\text {BANK OF AMERICA }}=X B S_{\text {BANK OF AMERICA }} * 5$ & & - & $-20.90 \%$ & $-11.75 \%$ & - & - & - \\
\hline $\mathrm{CAR}_{\mathrm{JPMORGAN}}=X B S_{J P M O R G A N} * 5$ & - & & - & - & - & - & - \\
\hline $\mathrm{CAR}_{\text {CITIGROUP }}=X B S_{\text {CITIGROUP }} * 5$ & - & - & & - & - & - & - \\
\hline $\mathrm{CAR}_{\mathrm{WELLS} \mathrm{FARGO}}=X B S_{\text {WELLS FARGO }} * 5$ & $25.30 \%$ & - & $29.40 \%$ & & - & - & - \\
\hline $\mathrm{CAR}_{\mathrm{GOLDMAN} \mathrm{SACHS}}=X B S_{\text {GOLDMAN SACHS }} * 5$ & - & - & $-27.10 \%$ & $-15.85 \%$ & & - & - \\
\hline $\mathrm{CAR}_{\text {MORGAN STANLEY }}=X B S_{\text {MORGAN STANLEY }} * 5$ & - & - & $21.15 \%$ & - & - & & $-5.90 \%$ \\
\hline $\mathrm{CAR}_{\mathrm{AMERICA} \text { EXPRESS }}=X B S_{\text {AMERICA EXPRESS }} * 5$ & $11.45 \%$ & - & - & - & - & $8.90 \%$ & \\
\hline
\end{tabular}


Table 7: Effects of cumulative specific announcements on banks' rates of return by area, POST period.

\begin{tabular}{|c|c|c|c|c|c|c|}
\hline \multirow{2}{*}{ VARIABLES AREA } & \multicolumn{3}{|c|}{ Model 1} & \multicolumn{3}{|c|}{ Model 2} \\
\hline & $\begin{array}{c}\text { WORLD } \\
(1) \\
\end{array}$ & $\begin{array}{c}\text { USA } \\
(2) \\
\end{array}$ & $\begin{array}{c}\text { EUROPE } \\
(3) \\
\end{array}$ & $\begin{array}{c}\text { WORLD } \\
(4) \\
\end{array}$ & $\begin{array}{c}\text { USA } \\
(5) \\
\end{array}$ & $\begin{array}{c}\text { EUROPE } \\
(6) \\
\end{array}$ \\
\hline Constant & $-0.00444 * * *$ & $-0.000910^{*}$ & $-0.00638 * * *$ & $-0.00434 * * *$ & $-0.000986^{*}$ & $-0.00621 * * *$ \\
\hline$R_{m}$ & $1.279 * * *$ & $1.664 * * *$ & $1.162 * * *$ & $1.279^{* * *}$ & $1.664 * * *$ & $1.162 * * *$ \\
\hline SIZEREL & $0.497 * * *$ & $0.253^{* *}$ & $1.108 * * *$ & $0.487 * * *$ & $0.260^{* *}$ & $1.076^{* * *} *$ \\
\hline$G^{A L L}$ & $0.00788^{* * *} *$ & $0.0129 * * *$ & 0.000773 & $0.00788 * * *$ & $0.0130^{* * *}$ & 0.000761 \\
\hline$R_{m} * G^{A L L}$ & $-0.0358 \#$ & $-0.241 * * *$ & $-0.100 * * *$ & $-0.0358 \#$ & $-0.241 * * *$ & $-0.0998 * * *$ \\
\hline$C U M 1_{S \geq 1} * R_{m}$ & $0.572 * * *$ & $0.396 * * *$ & $0.431 * * *$ & $0.572 * * *$ & $0.347 * * *$ & $0.425 * * *$ \\
\hline$C U M 1_{S \geq 1} * S I Z E R E L$ & 0.0535 & $-0.204^{*}$ & $0.219^{*}$ & 0.0700 & -0.148 & $0.184 \#$ \\
\hline$C U M 1_{S \geq 1} * G^{A L L}$ & $-0.00759 * * *$ & $-0.0107 * * *$ & $-0.0103^{* *}$ & $-0.00495^{* *}$ & $-0.0109^{* * *}$ & $0.0114^{*}$ \\
\hline$C U M 1_{S \geq 1} * R_{m} * G^{A L L}$ & $0.491 * * *$ & $0.673 * * *$ & $0.219^{*}$ & $0.453 * * *$ & $0.554 * * *$ & $0.550 * * *$ \\
\hline$C U M 2_{S \geq 2} * R_{m}$ & & & & 0.000204 & $0.234 * * *$ & 0.0130 \\
\hline$C U M 2_{S \geq 2} * S I Z E R E L$ & & & & -0.0440 & -0.0913 & 0.0801 \\
\hline$C U M 2_{S \geq 2} * G^{A L L}$ & & & & $-0.0110 * *$ & -0.00308 & $-0.0384 * * *$ \\
\hline$C U M 2_{S \geq 2} * R_{m} * G^{A L L}$ & & & & 0.164 & $0.762 * * *$ & $-0.612 * * *$ \\
\hline Bank Effect & $\mathrm{FE}$ & $\mathrm{RE}$ & $\mathrm{FE}$ & $\mathrm{FE}$ & $\mathrm{RE}$ & $\mathrm{FE}$ \\
\hline Observations & 38,745 & 15,060 & 15,065 & 38,745 & 15,060 & 15,065 \\
\hline $\mathrm{R}^{2}$ & 0.434 & 0.432 & 0.442 & 0.434 & 0.433 & 0.443 \\
\hline Number of bank & 116 & 45 & 45 & 116 & 45 & 45 \\
\hline F-Test $($ Prob $>$ F) & 0 & 0 & 0 & 0 & 0 & 0 \\
\hline WALD Test (Prob > chi2) & 0 & 0 & 0 & 0 & 0 & 0 \\
\hline Hausman Test (Prob > chi2) & 0 & 0.123 & 0.000600 & 0.00120 & 0.402 & 0.0106 \\
\hline $\mathrm{CAR}=C U M_{S \geq 1} * G^{A L L * 7}$ & $-5.313 \%$ & $-7.490 \%$ & $-7.210 \%$ & $-3.465 \%$ & $-7.630 \%$ & $7.980 \%$ \\
\hline $\mathrm{CAR}=C U M_{S>2} * G^{A L L_{* 7}}$ & & & & $-7.700 \%$ & - & $-26.880 \%$ \\
\hline
\end{tabular}

NOTES: POST $=15 / 09 / 2008$ to $31 / 12 / 2009 ; R_{m}=$ daily rate of return of the national stock exchange where bank $i$ is located; SIZEREL $=$ relative market capitalization of bank $i ; G=$ general announcement dummy; $A L L=$ all announcement types (capital injections and asset and debt guarantees). In Model $1, C U M 1=1$ when bank $i$ has received at least 1 specific announcements, 0 otherwise. In Model 2, CUMI = 1 when bank $i$ has received only 1 specific announcements, 0 otherwise; CUM2 $=1$ when bank $i$ has received at least 2 specific announcements; 0 otherwise. CAR $=$ cumulative abnormal returns with 5 day windows. All estimations include bank specific effects but fixed or random effects are reported according to the Hausman Test; UK banks excluded. WALD vs null cumulative specific announcement effects. No specific announcements in the Pacific area (not reported). ${ }^{* * *} \mathrm{p}<0.01 * * \mathrm{p}<0.05 * \mathrm{p}<0.10 \# \mathrm{p}<0.15$. 


\section{Appendix}

Table A1: List of banks included in market capitalization

\begin{tabular}{|c|c|c|c|}
\hline Area & Country & Bank Nr. & Bank Name \\
\hline \multirow{15}{*}{ Europe } & AT & 2 & ERSTE GROUP BANK AG, RAIFFEISEN INTL BANK HOLDING \\
\hline & $\mathrm{BE}$ & 2 & DEXIA SA, KBC GROEP NV \\
\hline & $\mathrm{CH}$ & 1 & VALIANT HOLDING AG-REG \\
\hline & $\mathrm{DE}$ & 3 & COMMERZBANK AG, DEUTSCHE POSTBANK AG, HYPO REAL ESTATE HOLDING \\
\hline & DK & 3 & DANSKE BANK A/S, JYSKE BANK-REG, SYDBANK A/S \\
\hline & ES & 6 & $\begin{array}{l}\text { BANCO BILBAO VIZCAYA ARGENTA, BANCO DE VALENCIA SA, BANCO } \\
\text { POPULAR ESPANOL, BANCO SANTANDER SA, BANKINTER SA }\end{array}$ \\
\hline & FR & 4 & BNP PARIBAS, CREDIT AGRICOLE SA, NATIXIS, SOCIETE GENERALE \\
\hline & GR & 5 & $\begin{array}{l}\text { ALPHA BANK A.E., BANK OF GREECE, EFG EUROBANK ERGASIAS, NATIONAL } \\
\text { BANK OF GREECE, PIRAEUS BANK S.A. }\end{array}$ \\
\hline & IE & 1 & ALLIED IRISH BANKS PLC \\
\hline & IT & 8 & $\begin{array}{l}\text { BANCA CARIGE SPA, BANCA MONTE DEI PASCHI SIENA, BANCA POPOLARE DI } \\
\text { MILANO, BANCO POPOLARE SCARL, INTESA SANPAOLO, PICCOLO CREDITO } \\
\text { VALTELLINESE, UBI BANCA SCPA, UNICREDIT SPA }\end{array}$ \\
\hline & NL & 2 & ING GROEP, SNS REAAL \\
\hline & NO & 1 & DNB NOR ASA \\
\hline & PT & 3 & BANCO BPI SA, BANCO COMERCIAL PORTUGUES, BANCO ESPIRITO SANTO \\
\hline & SE & 4 & $\begin{array}{l}\text { NORDEA BANK AB, SKANDINAVISKA ENSKILDA, SVENSKA HANDELSBANKEN } \\
\text { SHS, SWEDBANK AB }\end{array}$ \\
\hline & UK & 6 & $\begin{array}{l}\text { BANK OF IRELAND, BARCLAYS PLC, HSBC HOLDINGS PLC, LLOYDS BANKING } \\
\text { GROUP PLC, ROYAL BANK OF SCOTLAND, STANDARD CHARTERED PLC }\end{array}$ \\
\hline \multirow{3}{*}{ Pacific } & AU & 6 & $\begin{array}{l}\text { AUST AND NZ BANKING GROUP, BANK OF QUEENSLAND LTD, BENDIGO AND } \\
\text { ADELAIDE BANK, COMMONWEALTH BANK OF AUSTRALIA, NATIONAL } \\
\text { AUSTRALIA BANK LTD, WESTPAC BANKING CORP }\end{array}$ \\
\hline & HK & 8 & $\begin{array}{l}\text { BANK OF CHINA LTD, BANK OF COMMUNICATIONS CO, BANK OF EAST ASIA, } \\
\text { BOC HONG KONG HOLDINGS LTD, CHINA CONSTRUCTION BANK, HANG SENG } \\
\text { BANK LTD, HSBC HOLDINGS PLC, IND \& COMM BANK OF CHINA }\end{array}$ \\
\hline & JP & 12 & $\begin{array}{l}\text { BANK OF YOKOHAMA LTD, CHIBA BANK LTD, CHUO MITSUI TRUST HOLDINGS, } \\
\text { FUKUOKA FINANCIAL GROUP INC., MITSUBISHI UFJ FINANCIAL GROUP, } \\
\text { MIZUHO FINANCIAL GROUP INC, MIZUHO TRUST \& BANKING CO, RESONA } \\
\text { HOLDINGS INC, SHINSEI BANK LTD, SHIZUOKA BANK LTD, SUMITOMO MITSUI } \\
\text { FINANCIAL GROUP, SUMITOMO TRUST \& BANKING CO }\end{array}$ \\
\hline USA & US & 45 & $\begin{array}{l}\text { AMERICAN CAPITAL LTD, AMERICAN EXPRESS CO, AMERIPRISE FINANCIAL } \\
\text { INC, BANK OF AMERICA CORP, BANK OF NEW YORK MELLON CORP, BB\&T } \\
\text { CORP, CAPITAL ONE FINANCIAL CORP, CIT GROUP INC, CITIGROUP INC, CMA } \\
\text { GROUP INC, COMERICA INC, DISCOVERY FINANCIAL SERVICES, E*TRADE } \\
\text { FINANCIAL CORP, FEDERATED INVESTORS INC, FIFTH THIRD BANCORP, FIRST } \\
\text { HORIZON NATIONAL CORP, FRANKLIN RESOURCES INC, GOLDMAN SACHS } \\
\text { GROUP INC, HUDSON CITY BANCORP INC, HUNTINGTON BANCSHARES INC, } \\
\text { INTERCONTINENTALEXCHANGE INC, INVESCO LTD, JANUS CAPITAL GROUP } \\
\text { INC, JPMORGAN CHASE \& CO, KEYCORP, LEGG MASON INC, LEUCADIA } \\
\text { NATIONAL CORP, M \& T BANK CORP, MARSHALL \& ILSLEY CORP, MOODY'S } \\
\text { CORP, MORGAN STANLEY, NASDAQ OMX GROUP, NORTHERN TRUST CORP, } \\
\text { NYSE EURONEXT, PEOPLE'S UNITED FINANCIAL, PNC FINANCIAL SERVICES } \\
\text { GROUP, REGIONS FINANCIAL CORP, SCHWAB (CHARLES) CORP, SLM CORP, } \\
\text { STATE STREET CORP, SUNTRUST BANKS INC, T ROWE PRICE GROUP INC, US } \\
\text { BANCORP, WELLS FARGO \& CO, ZIONS BANCORPORATION }\end{array}$ \\
\hline
\end{tabular}

NOTES: AT=Austria; BE=Belgium; $\mathrm{CH}=$ Switzerland; DE=Germany; DK=Denmark; EI=Eire; ES=Spain; FR=France; $\mathrm{GR}=$ Greece; IT=Italy; NO=Norway; NL=Netherlands; PT=Portugal; SE=Sweden; UK=United Kingdom; AU=Australia; HK=Hong-Kong; JP=Japan; US=United States. 
Table A2: Timeline of general announcements (USD millions)

\begin{tabular}{|c|c|c|c|c|c|}
\hline \multirow[b]{2}{*}{ Data } & \multirow[b]{2}{*}{ Country } & \multicolumn{2}{|c|}{ Measure } & \multirow[b]{2}{*}{ Total } & \multirow[b]{2}{*}{ Cumulative } \\
\hline & & Capital Injections & $\begin{array}{c}\text { Asset and Debt } \\
\text { Guarantees }\end{array}$ & & \\
\hline $28 / 09 / 2008$ & NL & 29,192 & & 29,192 & 29,192 \\
\hline $30 / 09 / 2008$ & EI & 14,785 & 563,240 & 578,025 & 607,217 \\
\hline $02 / 10 / 2008$ & GR & 6,927 & & 6,927 & 614,144 \\
\hline $03 / 10 / 2008$ & US & 700,000 & & 700,000 & $1,314,144$ \\
\hline $05 / 10 / 2008$ & DK & - & & - & $1,314,144$ \\
\hline $07 / 10 / 2008$ & $\mathrm{ES}$ & 68,245 & 136,490 & 204,735 & $1,518,879$ \\
\hline \multirow[t]{2}{*}{$08 / 10 / 2008$} & IT & - & & - & \\
\hline & UK & 952,050 & 432,750 & $1,384,800$ & $2,903,679$ \\
\hline \multirow[t]{2}{*}{ 09/10/2008 } & IT & & 1,362 & 1,362 & \\
\hline & NL & 27,292 & & 27,292 & $2,932,333$ \\
\hline $10 / 10 / 2008$ & ES & 40,413 & 134,710 & 175,123 & $3,107,456$ \\
\hline \multirow[t]{3}{*}{$12 / 10 / 2008$} & AT & 18,669 & 93,345 & 112,014 & \\
\hline & $\mathrm{AU}$ & & 5,225 & 5,225 & \\
\hline & PT & & 26,942 & 26,942 & $3,251,637$ \\
\hline \multirow[t]{2}{*}{$13 / 10 / 2008$} & $\mathrm{DE}$ & 107,768 & 538,840 & 646,608 & \\
\hline & US & 250,000 & & 250,000 & $4,148,245$ \\
\hline \multirow[t]{3}{*}{$14 / 10 / 2008$} & HK & - & & - & \\
\hline & NL & & 273,160 & 273,160 & \\
\hline & US & & $2,250,000$ & $2,250,000$ & $6,671,405$ \\
\hline \multirow[t]{3}{*}{$16 / 10 / 2008$} & $\mathrm{BE}$ & & - & - & \\
\hline & $\mathrm{CH}$ & 60,000 & & 60,000 & \\
\hline & FR & 53,664 & 429,312 & 482,976 & $7,214,381$ \\
\hline $23 / 10 / 2008$ & GR & & 29,619 & 29,619 & $7,244,000$ \\
\hline $24 / 10 / 2008$ & $\mathrm{NO}$ & 1,459 & 51,071 & 52,530 & $7,296,530$ \\
\hline $29 / 10 / 2008$ & SE & & 195,277 & 195,277 & $7,491,807$ \\
\hline $05 / 11 / 2008$ & $\mathrm{CH}$ & & - & - & $7,491,807$ \\
\hline $24 / 11 / 2008$ & $\mathrm{PT}$ & 5,156 & & 5,156 & $7,496,963$ \\
\hline $28 / 11 / 2008$ & IT & - & & - & $7,496,963$ \\
\hline $08 / 12 / 2008$ & FR & 27,825 & & 27,825 & $7,524,789$ \\
\hline $10 / 12 / 2008$ & $\mathrm{BE}$ & & - & - & $7,524,789$ \\
\hline $17 / 12 / 2008$ & JP & 136,612 & & 136,612 & $7,661,401$ \\
\hline $18 / 01 / 2009$ & DK & 17,770 & & 17,770 & $7,679,171$ \\
\hline $19 / 01 / 2009$ & UK & & 73,685 & 73,685 & $7,752,856$ \\
\hline $03 / 02 / 2009$ & JP & 11,225 & & 11,225 & $7,764,080$ \\
\hline \multirow[t]{2}{*}{$10 / 02 / 2009$} & SE & 7,928 & & 7,928 & \\
\hline & US & 100,000 & & 100,000 & $7,872,008$ \\
\hline $12 / 02 / 2009$ & EI & 8,975 & & 8,975 & $7,880,984$ \\
\hline $25 / 02 / 2009$ & IT & 15,277 & & 15,277 & $7,896,261$ \\
\hline $06 / 03 / 2009$ & $\mathrm{DE}$ & - & & - & $7,896,261$ \\
\hline $17 / 03 / 2009$ & JP & 10,116 & & 10,116 & $7,906,377$ \\
\hline $23 / 03 / 2009$ & US & 500,000 & & 500,000 & $8,406,377$ \\
\hline $13 / 05 / 2009$ & $\mathrm{DE}$ & & 272,240 & 272,240 & $8,678,617$ \\
\hline $22 / 07 / 2009$ & $\mathrm{HK}$ & & - & - & $8,678,617$ \\
\hline Total & & $3,171,349$ & $5,507,268$ & $8,678,617$ & \\
\hline
\end{tabular}

NOTES: - = unspecified amount; AT=Austria; $\mathrm{BE}=$ Belgium; $\mathrm{CH}=$ Switzerland; DE=Germany; DK=Denmark; EI=Eire; ES=Spain; FR=France; GR=Greece; IT=Italy; NO=Norway; NL=Netherlands; PT=Portugal; SE=Sweden; UK=United Kingdom; AU=Australia; HK=Hong-Kong; JP=Japan; US=United States.

SOURCES: Mediobanca, BIS-BdI, DLA Piper, International Capital Market Association, and websites of national Ministries of Treasury or Finance. 
Table A3: Timeline of specific announcements (USD millions)

\begin{tabular}{|c|c|c|c|c|c|c|}
\hline \multirow[b]{2}{*}{ Data } & \multirow[b]{2}{*}{ Country } & \multirow[b]{2}{*}{ Bank } & \multicolumn{2}{|c|}{ Measure } & \multirow[b]{2}{*}{ Total } & \multirow[b]{2}{*}{ Cumulative } \\
\hline & & & $\begin{array}{c}\text { Capital } \\
\text { Injections }\end{array}$ & $\begin{array}{c}\text { Asset and Debt } \\
\text { Guarantees }\end{array}$ & & \\
\hline $14 / 03 / 2008$ & US & JP Morgan Chase \& Co & & 29,000 & 29,000 & 29,000 \\
\hline \multirow[t]{3}{*}{ 30/09/2008 } & $\mathrm{BE}$ & Dexia & 4,224 & & 4,224 & \multirow[b]{3}{*}{37,978} \\
\hline & FR & Dexia & 4,224 & & 4,224 & \\
\hline & LU & Dexia & 529 & & 529 & \\
\hline 06/10/2008 & $\mathrm{DE}$ & Hypo Real Estate & & 67,540 & 67,540 & 105,518 \\
\hline \multirow[t]{3}{*}{ 09/10/2008 } & $\mathrm{BE}$ & Dexia & & 123,837 & 123,837 & \multirow[b]{3}{*}{310,208} \\
\hline & FR & Dexia & & 74,712 & 74,712 & \\
\hline & $\mathrm{LU}$ & Dexia & & 6,141 & 6,141 & \\
\hline \multirow[t]{2}{*}{$13 / 10 / 2008$} & UK & Lloyds TSB & 28,963 & & 28,963 & \\
\hline & & RBS & 34,074 & & 34,074 & 373,245 \\
\hline $19 / 10 / 2008$ & NL & ING Groep & 13,462 & & 13,462 & 386,707 \\
\hline $22 / 10 / 2008$ & SE & Swedbank AB & \multirow{2}{*}{\multicolumn{2}{|c|}{4,356}} & 0 & 386,707 \\
\hline $27 / 10 / 2008$ & $\mathrm{BE}$ & KBC & & & 4,356 & 391,063 \\
\hline \multirow[t]{8}{*}{$28 / 10 / 2008$} & \multirow[t]{8}{*}{ US } & Bank of America & 15,000 & & 15,000 & \multirow[b]{8}{*}{506,063} \\
\hline & & Bank of New York Mellon & 3,000 & & 3,000 & \\
\hline & & Citigroup & 25,000 & & 25,000 & \\
\hline & & Goldman Sachs Group & 10,000 & & 10,000 & \\
\hline & & JP Morgan Chase \& Co & 25,000 & & 25,000 & \\
\hline & & Morgan Stanley & 10,000 & & 10,000 & \\
\hline & & State Street Corp & 2,000 & & 2,000 & \\
\hline & & Wells Fargo Bank & 25,000 & & 25,000 & \\
\hline $30 / 10 / 2008$ & $\mathrm{DE}$ & Hypo Real Estate & & 19,275 & 19,275 & 525,338 \\
\hline $03 / 11 / 2008$ & $\mathrm{DE}$ & Commerzbank & 6,321 & 19,079 & 25,400 & 550,738 \\
\hline $07 / 11 / 2008$ & US & Franklin Resources & 1,600 & & 1,600 & 552,338 \\
\hline $12 / 11 / 2008$ & $\mathrm{NL}$ & SNS Reaal & 942 & & 942 & 553,280 \\
\hline $13 / 11 / 2008$ & $\mathrm{DE}$ & Hypo Real Estate & & 25,052 & 25,052 & 578,332 \\
\hline \multirow[t]{11}{*}{$17 / 11 / 2008$} & \multirow[t]{11}{*}{ US } & BB\&T Corp & 3,134 & & 3,134 & \multirow[b]{11}{*}{608,610} \\
\hline & & Capital One Financial Corp & 3,555 & & 3,555 & \\
\hline & & Comerica & 2,250 & & 2,250 & \\
\hline & & First Horizon National Corp & 867 & & 867 & \\
\hline & & Huntington Bancshares & 1,398 & & 1,398 & \\
\hline & & Key Corp & 2,500 & & 2,500 & \\
\hline & & Northern Trust Corp & 1,576 & & 1,576 & \\
\hline & & Regions Financial Corp & 3,500 & & 3,500 & \\
\hline & & Sun Trust Banks & 3,500 & & 3,500 & \\
\hline & & US Bancorp & 6,599 & & 6,599 & \\
\hline & & Zions Bancorporation & 1,400 & & 1,400 & \\
\hline $21 / 11 / 2008$ & $\mathrm{DE}$ & Hypo Real Estate & & 25,062 & 25,062 & 633,672 \\
\hline $23 / 11 / 2008$ & US & Citigroup & 20,000 & 262,000 & 282,000 & 915,672 \\
\hline $25 / 11 / 2008$ & $\mathrm{PT}$ & Banco Espirito Santo & & 1,955 & 1,955 & 917,627 \\
\hline $09 / 12 / 2008$ & $\mathrm{DE}$ & Hypo Real Estate & & 12,937 & 12,937 & 930,564 \\
\hline \multirow[t]{3}{*}{$11 / 12 / 2008$} & \multirow[t]{3}{*}{ FR } & BNP Paribas & 3,390 & & 3,390 & \multirow[b]{3}{*}{940,202} \\
\hline & & Crédit Agricole & 3,988 & & 3,988 & \\
\hline & & Societé Générale & 2,260 & & 2,260 & \\
\hline
\end{tabular}




\begin{tabular}{|c|c|c|c|c|c|}
\hline \multirow{2}{*}{$21 / 12 / 2008$} & \multirow{2}{*}{ EI } & Allied Irish Banks & 2,775 & \multicolumn{2}{|l|}{2,775} \\
\hline & & Bank of Ireland Group & 2,775 & 2,775 & 945,752 \\
\hline $23 / 12 / 2008$ & US & M\&T Bank Corp & 600 & 600 & 946,352 \\
\hline \multirow{6}{*}{$31 / 12 / 2008$} & $\mathrm{DE}$ & Commerzbank & 13,919 & 13,919 & \\
\hline & US & CIT Group & 2,330 & 2,330 & \\
\hline & & Citigroup & 20,000 & 20,000 & \\
\hline & & Fifth Third Bancorp & 3,408 & 3,408 & \\
\hline & & PNC Financial Services Group & 7,579 & 7,579 & \\
\hline & & Sun Trust Banks & 1,350 & 1,350 & 994,938 \\
\hline $08 / 01 / 2009$ & $\mathrm{DE}$ & Commerzbank & 6,857 & 6,857 & $1,001,795$ \\
\hline \multirow{2}{*}{ 09/01/2009 } & US & American Express Company & 3,389 & 3,389 & \\
\hline & & Bank of America & 10,000 & 10,000 & $1,015,184$ \\
\hline \multirow[t]{2}{*}{$12 / 01 / 2009$} & GR & Alpha Bank AE & 1,268 & 1,268 & \\
\hline & & EFG Eurobank Ergasias & 1,268 & 1,268 & $1,017,720$ \\
\hline $14 / 01 / 2009$ & AT & Erste Group Bank & 7,904 & 7,904 & $1,025,624$ \\
\hline \multirow[t]{2}{*}{$16 / 01 / 2009$} & US & Bank of America & 97,000 & 117,000 & \\
\hline & & Citigroup & 7,000 & 7,000 & $1,149,624$ \\
\hline $19 / 01 / 2009$ & NL & SNS Reaal & 2,649 & 2,649 & $1,152,273$ \\
\hline $20 / 01 / 2009$ & $\mathrm{DE}$ & Hypo Real Estate & 15,535 & 15,535 & $1,167,808$ \\
\hline \multirow{2}{*}{$22 / 01 / 2009$} & $\mathrm{BE}$ & $\mathrm{KBC}$ & 2,591 & 2,591 & \\
\hline & GR & National Bank of Greece & 453 & 453 & $1,170,853$ \\
\hline $23 / 01 / 2009$ & GR & Pireus Bank & 475 & 475 & $1,171,328$ \\
\hline $26 / 01 / 2009$ & NL & ING Groep & 28,346 & 28,346 & $1,199,674$ \\
\hline $30 / 01 / 2009$ & NL & ING Groep & 14,597 & 14,597 & $1,214,270$ \\
\hline 05/02/2009 & AT & Raiffeisen Zentralbank Osterreich AG & 1,926 & 1,926 & $1,216,196$ \\
\hline $10 / 02 / 2009$ & $\mathrm{DE}$ & Hypo Real Estate & 12,966 & 12,966 & $1,229,162$ \\
\hline \multirow{2}{*}{$12 / 02 / 2009$} & EI & Allied Irish Banks & 1,923 & 1,923 & \\
\hline & & Bank of Ireland Group & 1,923 & 1,923 & $1,233,009$ \\
\hline $20 / 02 / 2009$ & NL & ING Groep & 4,000 & 4,000 & $1,237,009$ \\
\hline $26 / 02 / 2009$ & UK & RBS & 466,115 & 484,760 & $1,721,768$ \\
\hline $27 / 02 / 2009$ & AT & Erste Group Bank & 3,419 & 3,419 & $1,725,187$ \\
\hline 05/03/2009 & NL & SNS Reaal & 2,513 & 2,513 & $1,727,700$ \\
\hline $07 / 03 / 2009$ & UK & Lloyds TSB & 366,860 & 366,860 & $2,094,560$ \\
\hline $10 / 03 / 2009$ & IT & Banco Popolare & 1,849 & 1,849 & $2,096,409$ \\
\hline $12 / 03 / 2009$ & NL & ING Groep & 2,000 & 2,000 & $2,098,409$ \\
\hline \multirow[t]{4}{*}{$13 / 03 / 2009$} & AT & Raiffeisen Zentralbank Osterreich AG & 1,611 & 1,611 & \\
\hline & $\mathrm{BE}$ & Dexia & 15,082 & 15,082 & \\
\hline & US & Discover Financial Services & 1,225 & 1,225 & \\
\hline & & Morgan Stanley & 1,225 & 1,225 & $2,117,552$ \\
\hline $18 / 03 / 2009$ & IT & Unicredit Group & 2,622 & 2,622 & $2,120,174$ \\
\hline $20 / 03 / 2009$ & IT & Intesa Sanpaolo & 5,426 & 5,426 & $2,125,600$ \\
\hline $24 / 03 / 2009$ & IT & Banca Popolare di Milano & 676 & 676 & $2,126,277$ \\
\hline $27 / 03 / 2009$ & IT & Banca Monte dei Paschi di Siena & 2,528 & 2,528 & $2,128,805$ \\
\hline 28/03/2009 & $\mathrm{DE}$ & Hypo Real Estate & 79,703 & 79,703 & $2,208,508$ \\
\hline $31 / 03 / 2009$ & FR & BNP Paribas & 6,763 & 6,763 & $2,215,271$ \\
\hline $04 / 04 / 2009$ & US & Bank of America & 799 & 799 & $2,216,070$ \\
\hline \multirow[t]{3}{*}{$13 / 04 / 2009$} & US & Citigroup & 2,071 & 2,071 & \\
\hline & & JP Morgan Chase \& Co & 2,700 & 2,700 & \\
\hline & & Wells Fargo Bank & 2,873 & 2,873 & $2,223,713$ \\
\hline
\end{tabular}




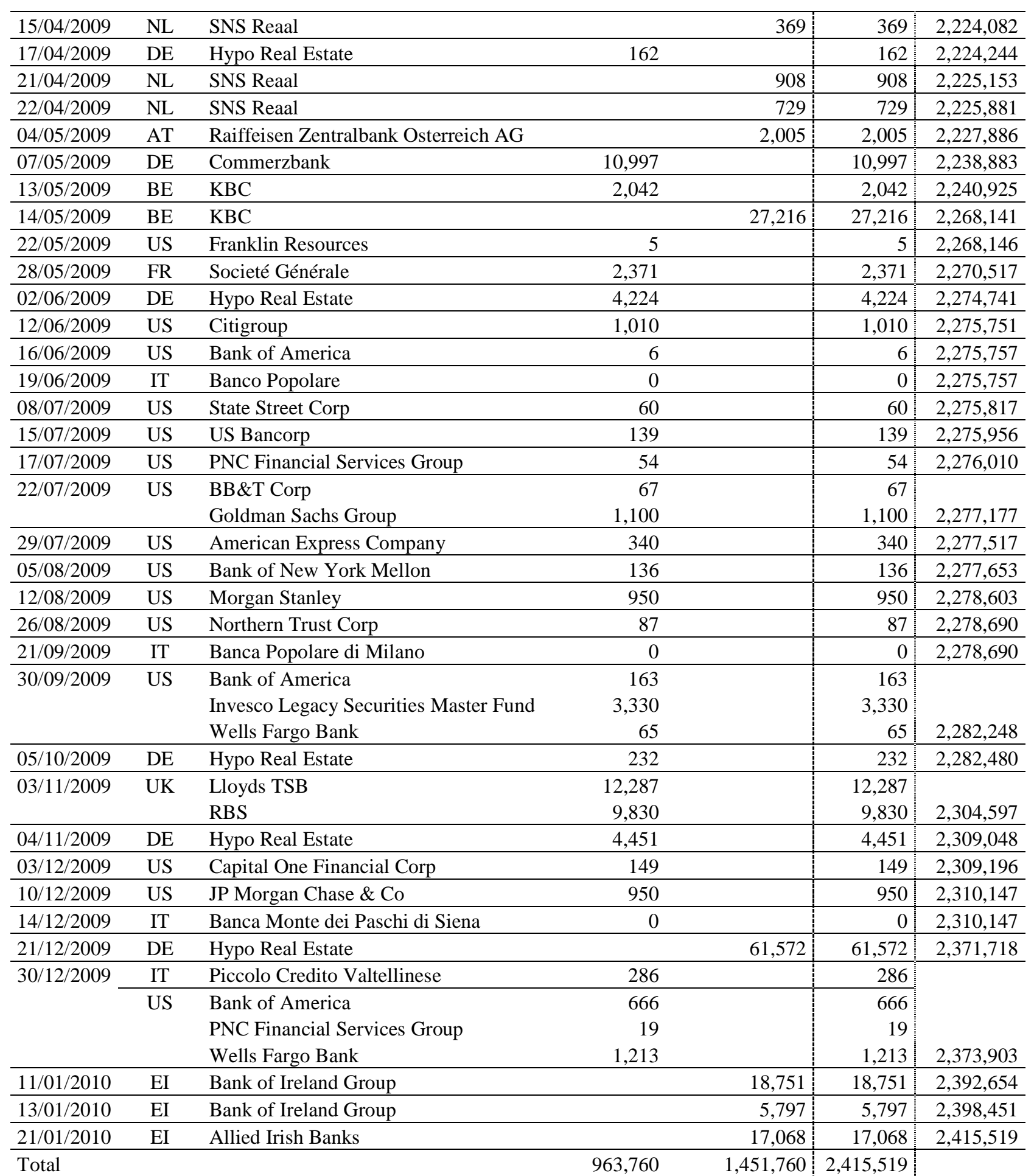

NOTES: We exclude expenses for failures because we have data only for US; AT=Austria; $\mathrm{BE}=\mathrm{Belgium}$; $\mathrm{CH}=\mathrm{Switzerland}$; $\mathrm{DE}=$ Germany; DK=Denmark; EI=Eire; ES=Spain; FR=France; GR=Greece; IT=Italy; NO=Norway; NL=Netherlands; PT=Portugal; $\mathrm{SE}=$ Sweden; UK=United Kingdom; AU=Australia; HK=Hong-Kong; JP=Japan; US=United States.

SOURCES: Mediobanca, BIS-BdI, and CNN Money. 